\title{
Identification of Effective Factors Decision Making in Crisis in Media rganization: A Systematic Review with Emphasis on Media literacy in Health Crisis (CORONA PANDEMIC)
}

\begin{abstract}
Background and Objective: Decision making as a basis of management is like a nervous system of an organization and crisis is effective in decision making processes. This study aimed to analysing available researches about decision making in crisis in media organizations.

Materials and Methods: This systematic review was implemented from March to June 2020.English language publications (2000-2019) were filtered in databases of Willey, Elsevier, ISI, Pubmed, SCOPUS and Google Scholar search engine by combination of following Keywords:"Decision making"AND"Media"AND"Crisis"in title, abstract and keywords.

Results: After searching 6155 papers and removing repeated and unrelated ones, finally 14 papers were selected for deep analysis according to items identified. Results of this systematic review indicated that following factors are effective in descion making in crisis:"Attention to time of content production, Agile organizations, Decision-making models, Method of news coverage continuation ,Effects of place on crisis management ","Creating the trust, Recording experiences before during and after the crisis, Shortage of human resources in crisis, Interactive nature of social medias,Attention to panoramic dimension of the crisis, Time of the crisis, using tools of social medias and attention to new media trends".

Conclusion: In health crisis (Corona Pandemic) Convincing use of communicational message by media organizations with the goal of effecting in belief, attitude and health behaviors of society is necessary. Meanwhile designing a big and panoramic picture of all related dimentions of media and health and attention to "Media litracy" and "Health litracy" of media managers besides designing and implementing researches based on descion making methods development in crisis and also benefit of other countirs experiences will leads to effective descion making in health system.

Keywords: Media management, crisis management, decision making, media litracy, systematic review

Paper Type: Research Article.
\end{abstract}

Citation (Vancouver): Izadi L, Taghdisi MH, Ghadami M, Saroukhani B, Delavar A. Identification of Effective Factors Decision Making in Crisis in Media rganization: A Systematic Review with Emphasis on Media literacy in Health Crisis (CORONA PANDEMIC). Iran J Health Educ Health Promot. Winter 2021;8(4): 390-406. [Persian]x

- Citation (APA): Izadi L., Taghdisi MH., Ghadami M., Saroukhani B., Delavar A. Identification of Effective Factors Decision Making in Crisis in Media rganization: A Systematic Review with Emphasis on Media literacy in Health Crisis (CORONA PANDEMIC). Iranian Journal of Health Education \& Health Promotion., 8(4), 390-406 . [Persian]
Loya Izadi

PhD candidate of Media Management, Department of Management and Economy, Science and Research Branch. Islamic Azad University, Tehran, Iran.

Mohammad Hossein Taghdisi

* Health Promotion, PhD. Public Health Department, School of Health and Medica Engineering, Islamic Azad University Tehran Medical Sciences, Tehran, Iran. (corresponding author) taghdisi.mh@gmail.com Mohsen Ghadami

Professor, Department of Management and Economy, Science and Research Branch. Islamic Azad University, Tehran, Iran.

\section{Bagher Saroukhani}

Professor, Department of Social Science, University of Tehran, Tehran, Iran.

Ali Delavar

Professor, Department of Psychology and Education Science, Alameh Tabatabayi University, Tehran, Iran

Received: 2020/07/12

Accepted: 2020/09/16

Doi: 10.29252/ijhehp.8.4.1 


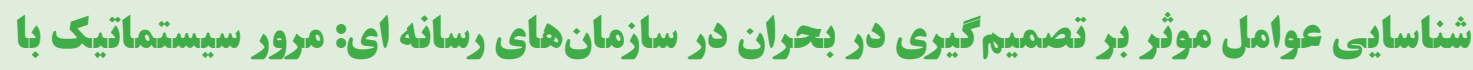

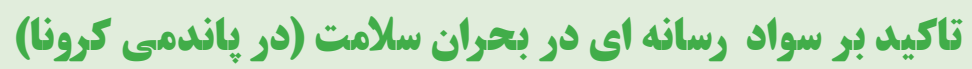

لويا ايزدى د داندي

دانشجوى دكتراى رشته مديريت رسانه، دانشكده

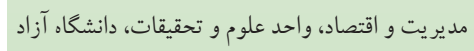
اسلامى، تهران، ايران

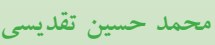
استاد ارتقاء سلامت، گرووه يهداشت عمومى، دانشكده

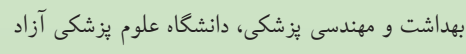
اسلامى تهران(نويسنده مسئول) taghdisimh@gmail.com

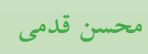

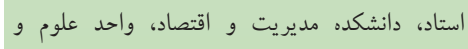
تحقيقات, دانشخاه آزاد اسلامى، تهران، ايران. باقر ساروخانى استاد، دانشكده علوم اجتماعى، دانشكاء تهران،

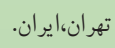
على دلاور

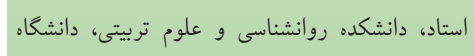
علامه طباطبايى، تهران، ايران.

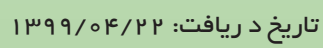

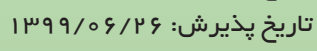

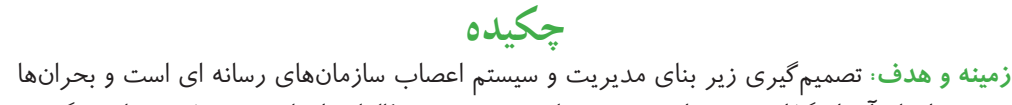

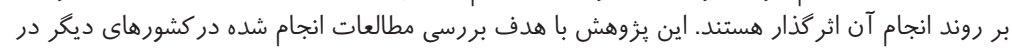

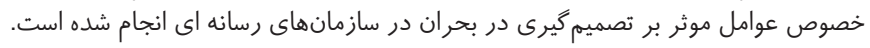

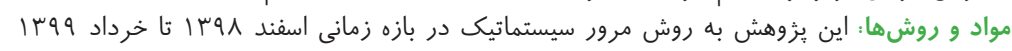

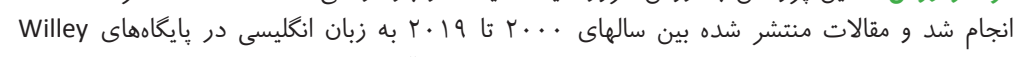
Decision making AND Media AND"Elsevier,Pubmed,SCOPUS,ISI

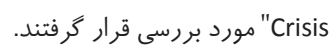

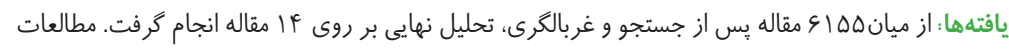

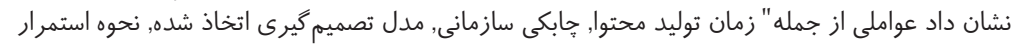

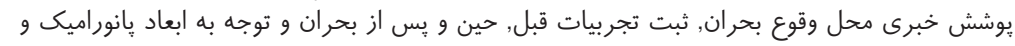

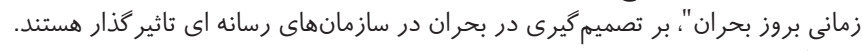

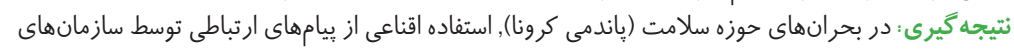

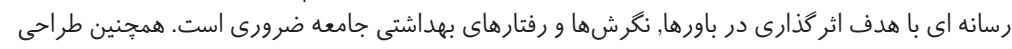

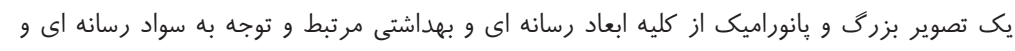

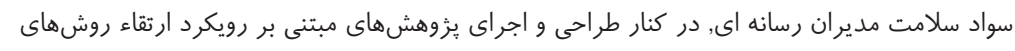

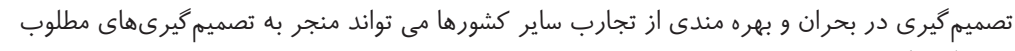
در نظام سلامت شود.

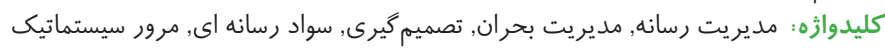

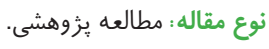

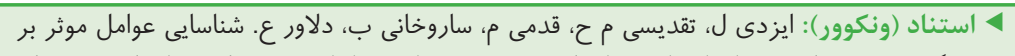

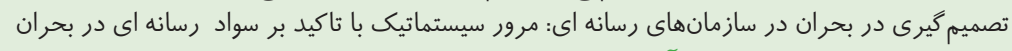

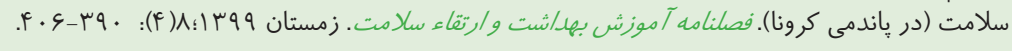

4 استناد (APA) : ايزدى، لويا؛ تقديسى، محمد حسين؛ قدمى، محسن؛ ساروخانى، باقر : دلاور، على. (زمستان

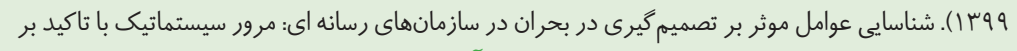

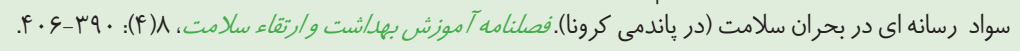


بحر ان در سـازمان هاى مختلف يرداخت و جنين نتيجه كيرى نمود

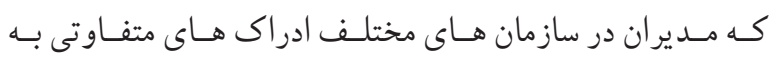

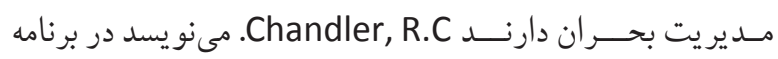
ريزى مديريت بحران بايد به اختلافـات فرهنحسى توجـه داشت. Hatch M. Cunlif

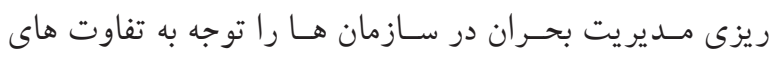

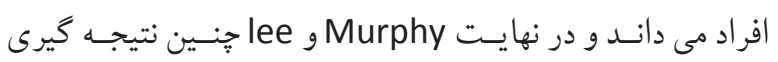

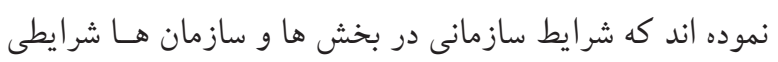

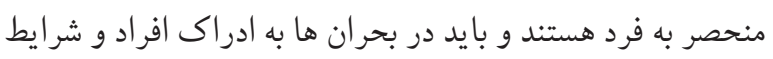

$$
\text { خاص آنها توجه داشت (†) (Y). }
$$

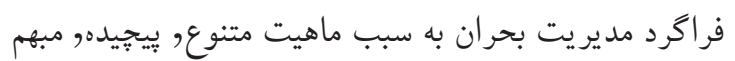

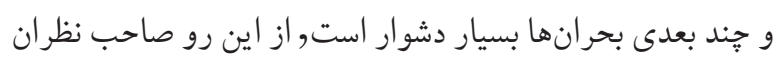

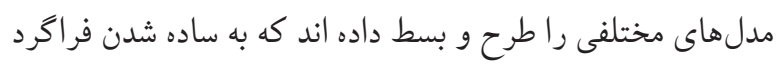

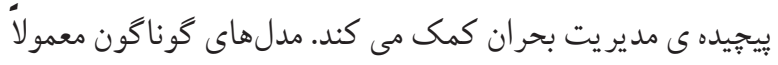

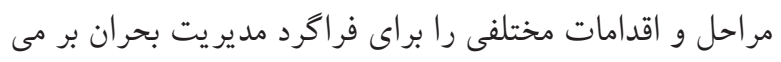

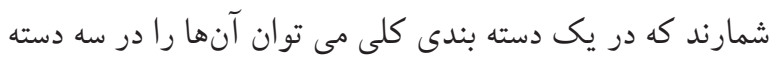

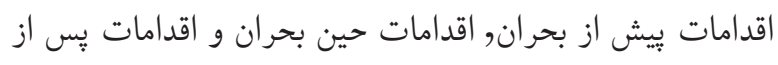

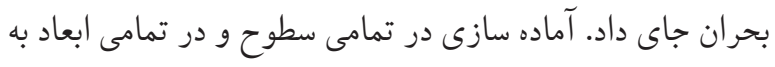

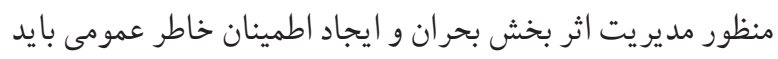

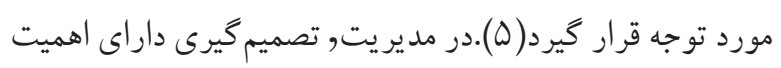

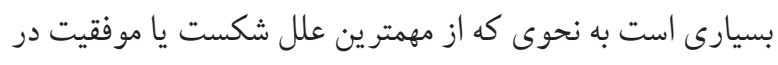

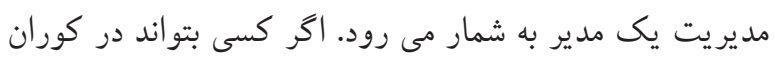
حوادث به خوبى تصميم بكيرد، فردى موفق به حساب مى ئ آيد. زيرا

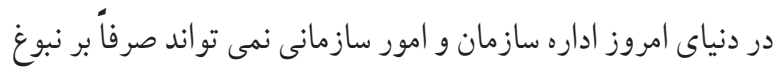
و قضاوت شخصى افراد متكى باشد بلكه تصميمات بايستى حتى

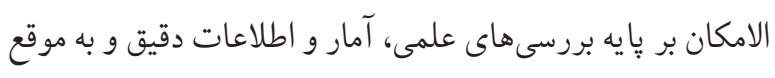

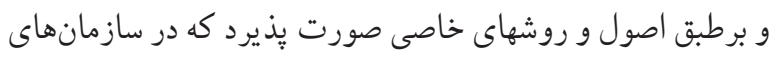

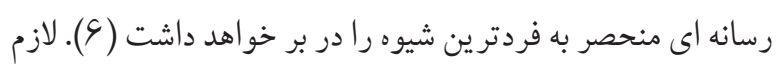
به ذكر است بيشترين جالشهاى حوزه مديريت در سازمانهاى بهاى

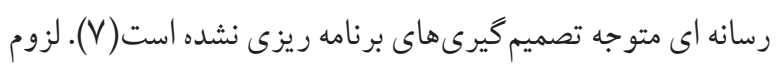

توليد و كسترش روز افزون اطلاعات در نهايت منجر به ايجاد آسيبهايى در زندگى كارى و اجتماعى افراد خواهد شود . Alvin Toffler

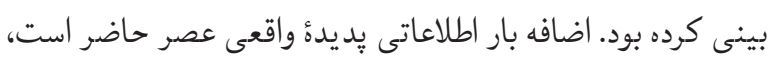

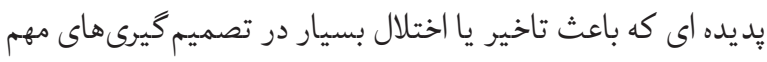

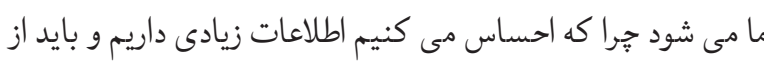

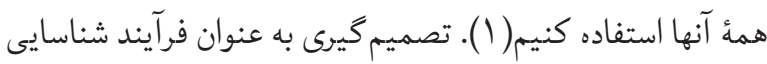
و حل مسئله از نظر نوع به دو دسته مهم قابل تقسيم بندى است,

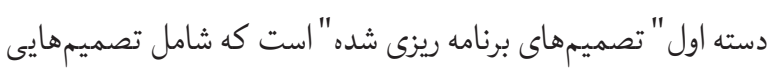

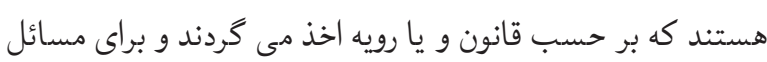

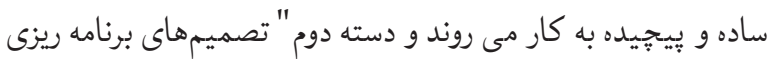

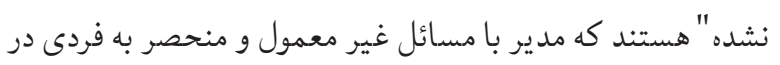

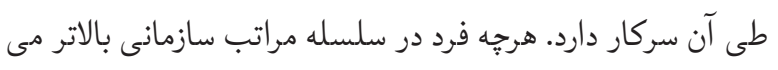

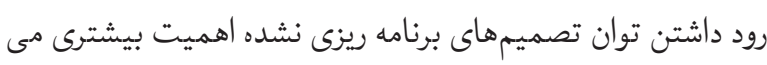

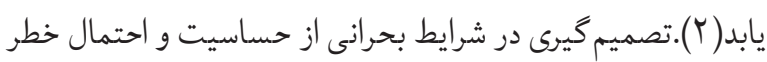
بالاترى نسبت به شرايط عادى برخوردار است. شرايط خاص بحرانى لهري

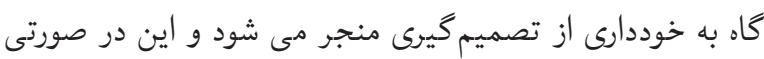
كه به عمد و آكاهانه باشد خود يك تصميم شمرده مى شود (َّ).

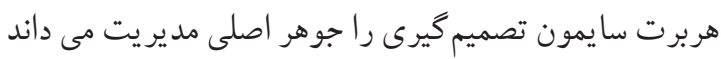

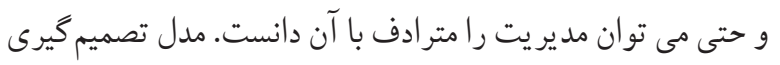

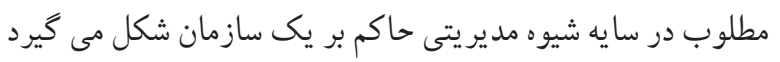

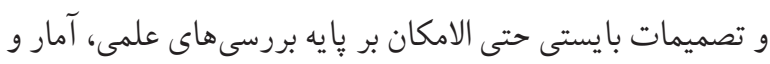

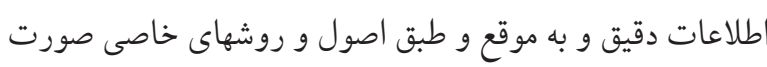

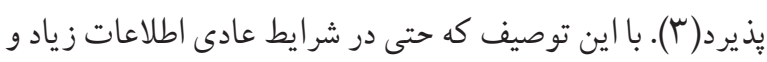

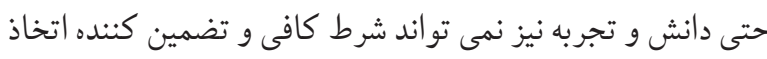

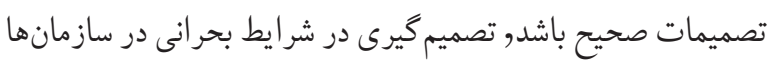

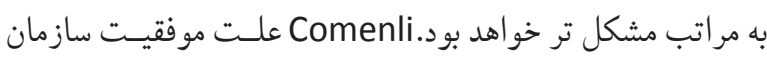

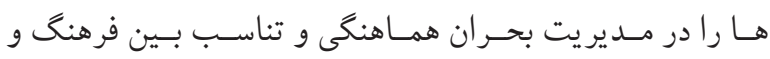

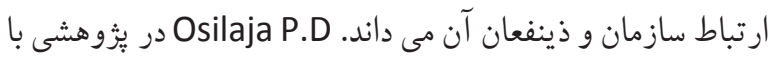
عنوان موضوع تفـاوت در مديريت بحران به بررسى ادراك مديران 
انجام مرور سيستماتيك مقالات موجود در حوزه تصميم گيرى در بحر ان در سازمانهاى رسانه اى انجام شده است.

مو اد و روش ها

هدف اصلى يُوهش حاضر بررسى مطالعات انجام شده در كشورهاى

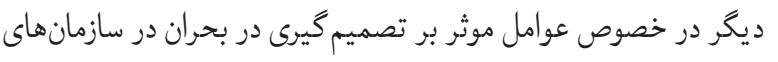

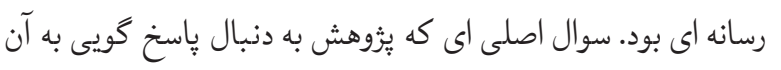

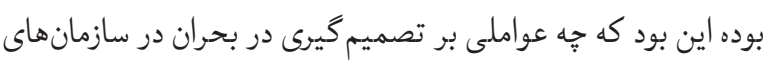

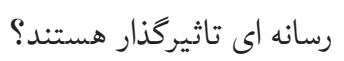

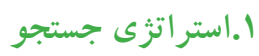

به منظور جستجوى مطالعات مرتبط در يُزوهش حاضر كه مطالعه اى به روش مرور سيستماتيك بود جستجو در بازه زمانى اسفند

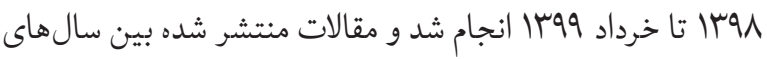

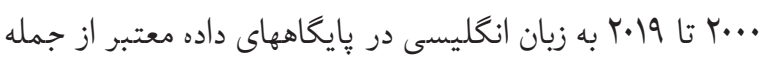
Willey, Elsevier, Pubmed,SCOPUS,ISI Decision" با استفاده از مجموعه كليد واثرهاى Google Scholar "making AND Media AND Crisis كليدى مورد بررسى قرار كرفتند. از MESH نيز جهت تعيين كلمات كليدى استفاده شد و در نهايت جستجوى عبارات در ورايخاههاى اطلاعاتى ذكر شده توسط دو متخصص در حوزه رسانه صورت گرفت. بدين ترتيب راهبرد اصلى جست و جو در يايخاههاى داده معتبر

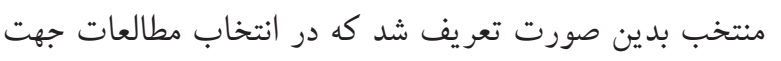

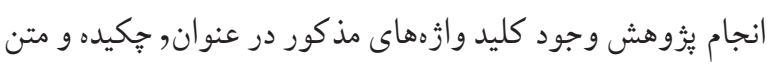

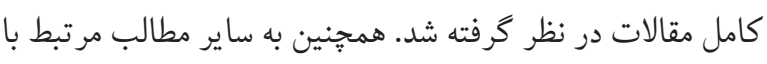

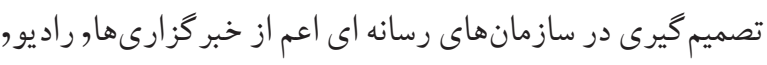

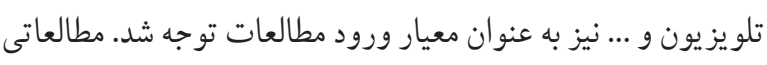
كه در عنوان و جركيده مرتبط با تصميم گيرى در بحران و رسانهها

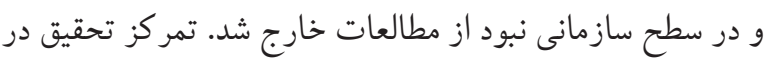

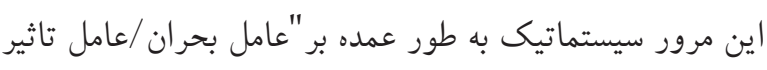

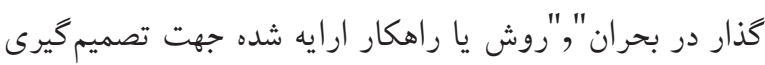
در بحران" و"روش تحقيق استفاده شده" بود.
داشتن سو اد رسانهاى به اين مفهوم كه افراد تو انمندى جِكونكى حسن استفاده از رسانهها را داشته باشند تا مزاياى رسانهها را دان در اختيار

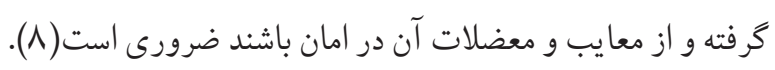

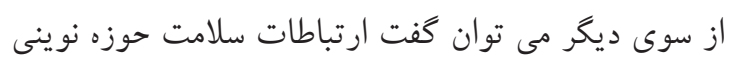
است كه تمر كز خود را بر ((نقش قدرتمندى)) كه ارتباطات انسانى دونى

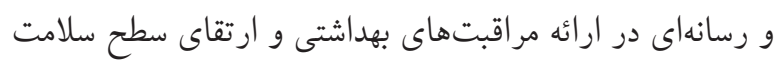

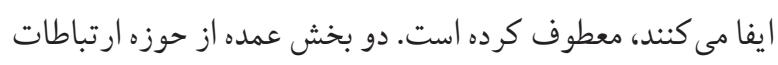

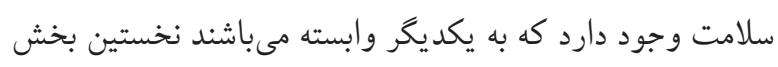

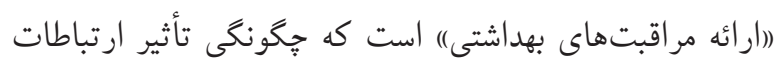

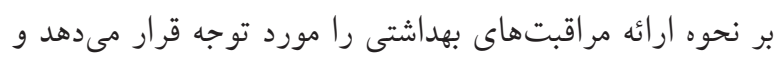

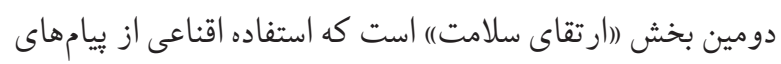

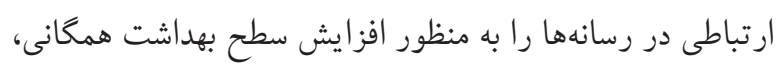

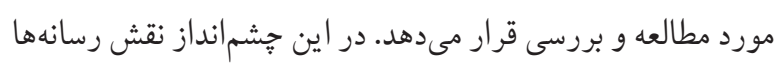
در سلامت به عنوان يك عامل اثر گذار و تعيين كننده در باورها،

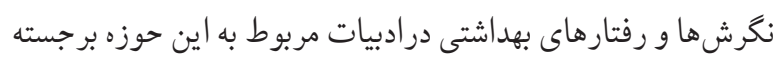
مىشود(9). سواد سلامت را ميزان ظرفيت فرد براى كسب، تفسير

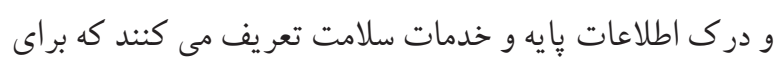
تصميم گيرى مناسب لازم است همجنين آن را به عنوان طيف خستردهاي

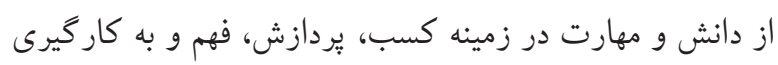
اطلاعات سلامت نيز تعريف مى كنند ( • (). تبيين مقوله تصميم كيرى در بحران با توجه به مفاهيم سواد

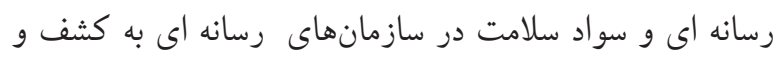
بازنكرى نياز دارد. توجه به عوامل موثر بر تصميم گيرى در بحران

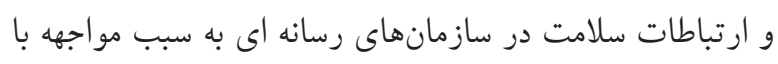

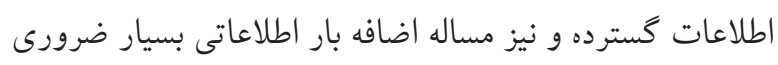

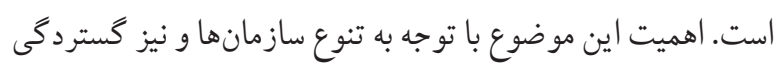

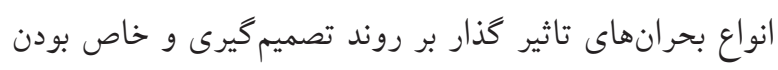

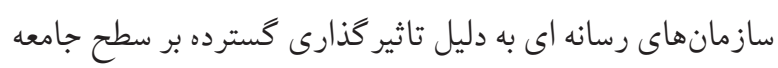

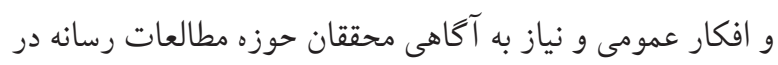

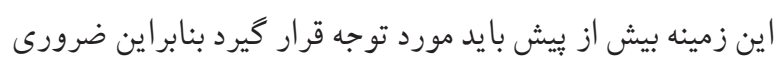

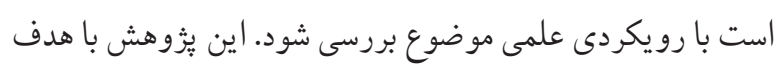


حذف مقالاتى كه بيش از يكبار در نتايج جستجو وجود داشتند

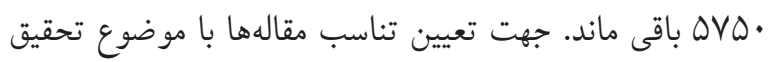

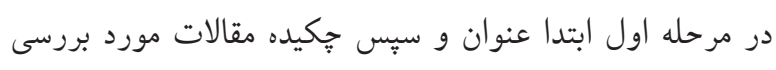

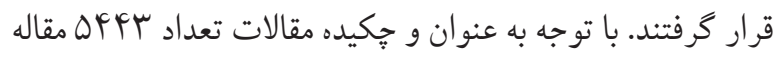

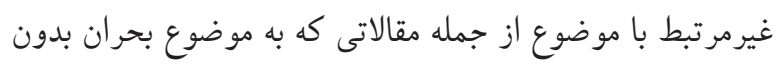

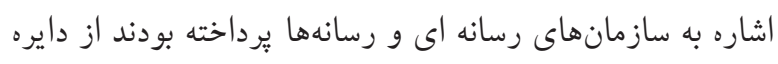

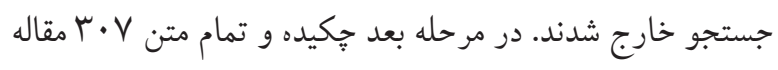
باقى مانده به طور عميق تر مطالعه شد و در اين مرحله نيز مقالاتى تردي

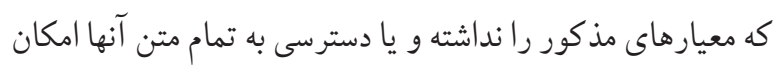

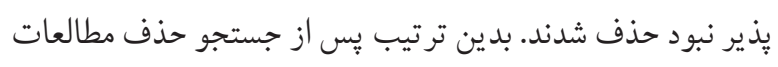

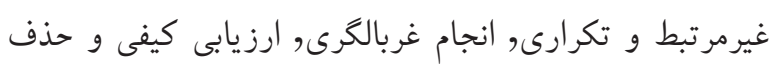

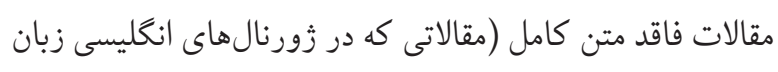

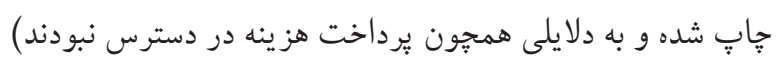

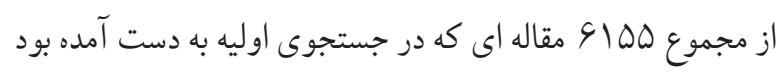
تعداد fl أمقاله واجد شرايط مطالعه حاضر شناخته شدند و تحليل نهايى بر روى آنها انجام كرفت.

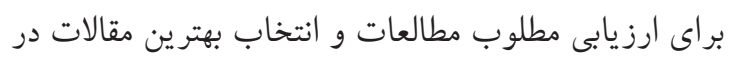
فرايندى انتقادى با هدف ارزيابى كيفيت روش شناسى تحقيق و ورئ

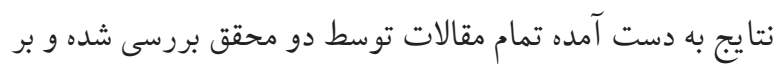
اساس نتايج اين بررسى مطالعات در مرور سيستماتيك استفاده و يا از مطالعه خارج شدند. درضمن مقالات استخراج شده وارد نرم

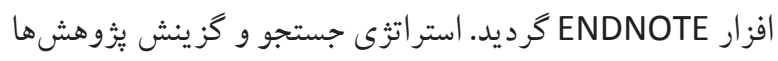
بر اساس" "PRISMA"در شكل شماره ا آورده شده است. در طى اجراى مرور سيستماتيك يس از انجام جستجو بر مبناى استراتزىهاى تعريف شدهو بررسى كيفى مطالعات, تحليل نهايى دروني

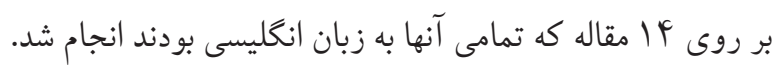

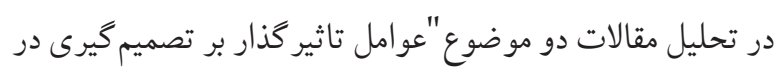

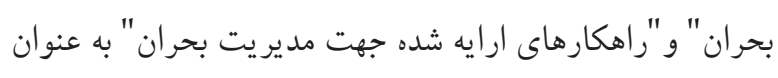

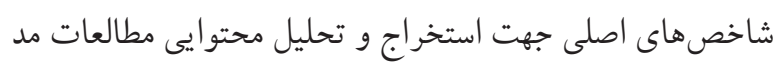

نظر قرار كرفت. در نهايت يافتهها در دو بخش ارايه كرديد.

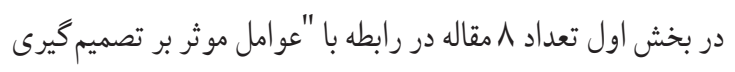

r. r. معيارهاى ورود و خروج مقالات

تاريخ انتشار؛ به دليل جامعيت و كسترد كى معنايى وازثًان" Decision "و و با توجه به نقش ير رنغ رسانهها

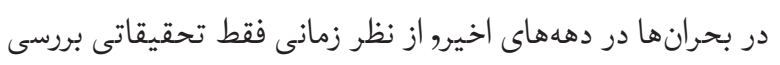

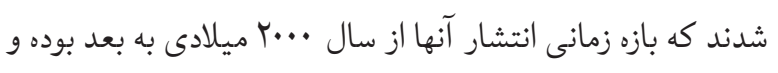
به زبان انحليسى منتشر شده بودند

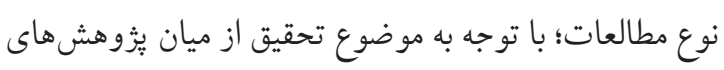

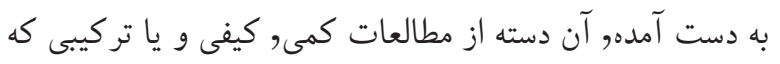

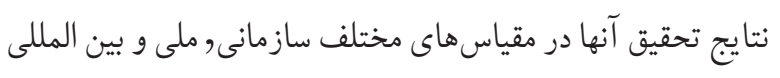
ارايه شده بودند بررسى شد. "ا.استخر اج دادهها براى استخراج دادها از جّى ليست محقق ساخته استفاده شد و

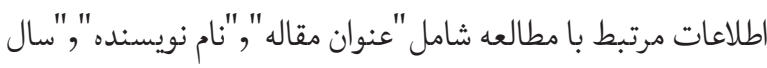
انتشار","نوع مطالعه","هدف تحقيق","عامل بحران/عامل تاثير

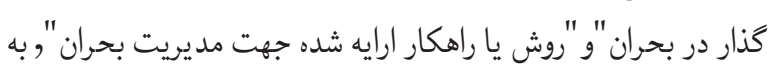

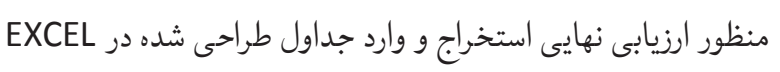

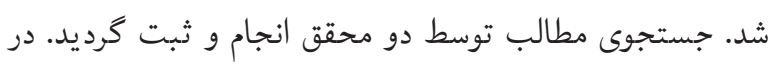

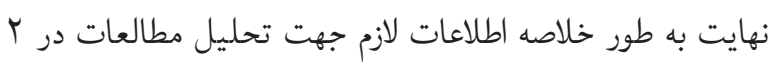

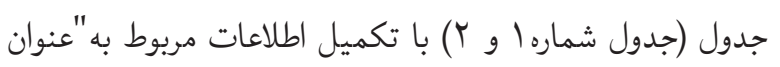

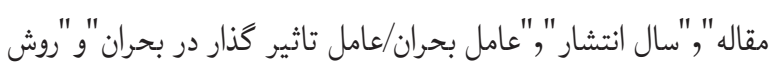
يا راهكار ارايه شده جهت مديريت بحران"دسته بندى و جهت تحليل نهايى بررسى شد.

يافته ها يافتهایى اين بُزوهش نشان داد در بازه زمانى مذكور 9V درصد از

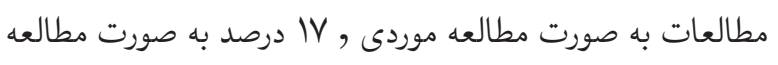
تحليلى و IV درصد نيز به صورت مطالعه تركيبى انجام شده و

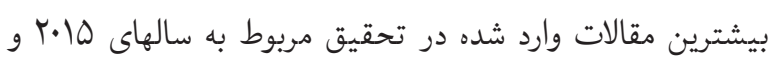

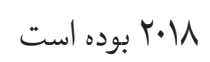
با به كاربردن استراتزىهاى جستجو و استفاده از عملكرهاى OR ور نتايج اوليه ابتدا OD AND 


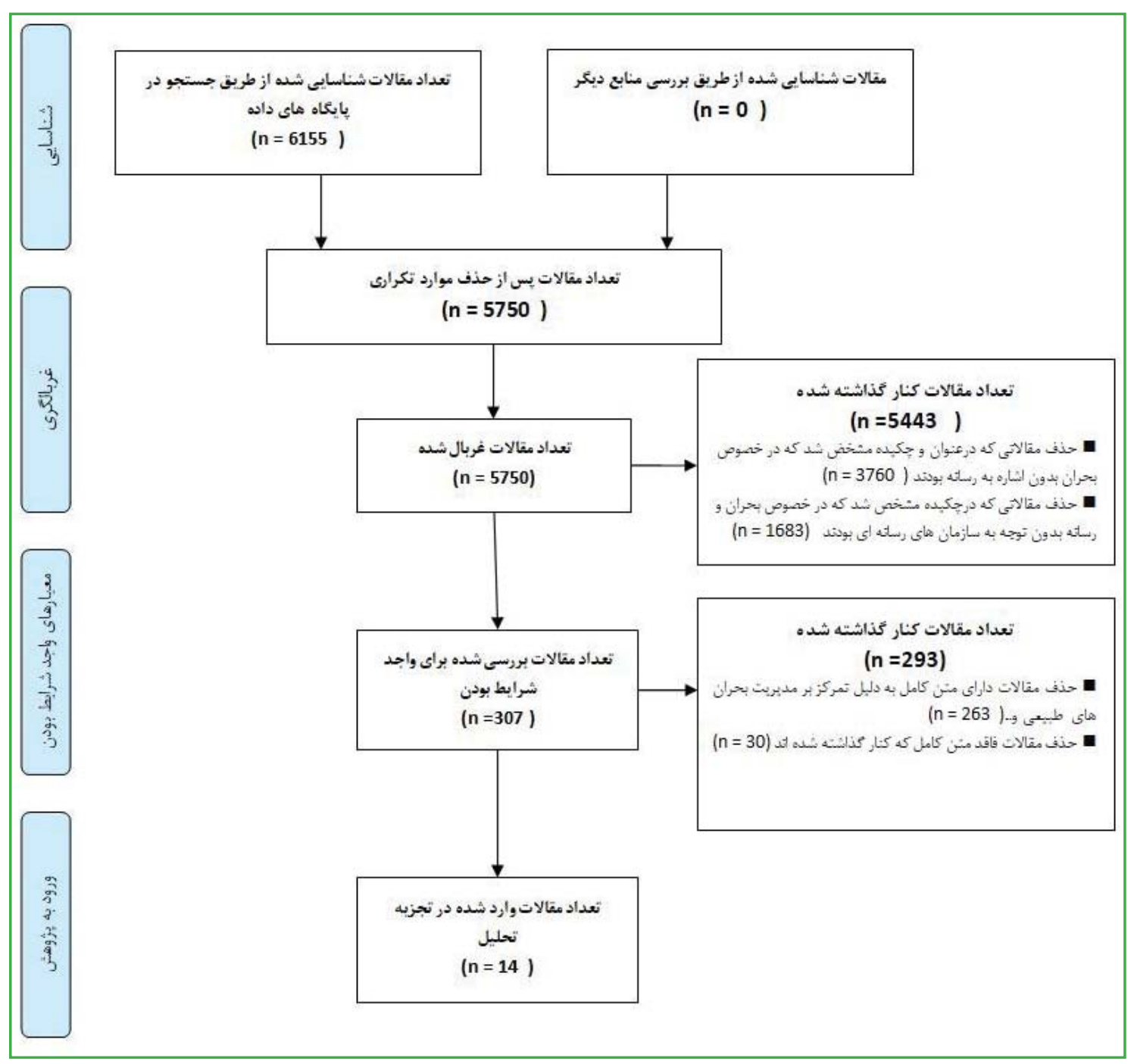

شكل ا. فلوخارت جستجو و كَزينش يخوهشهاو

در بحران با لحاظ رسانهاى اجتماعى"( جدول شماره ) بررسى در حال حاضر در شرايط بحرانى در اختيار افراد قرار دارد.به دليل

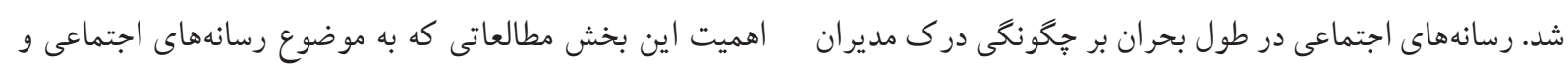

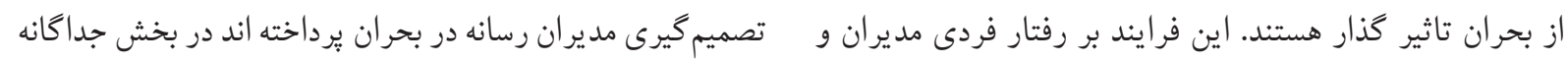

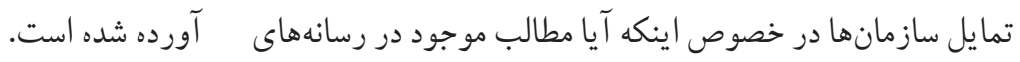

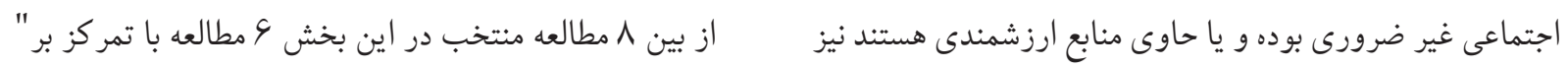

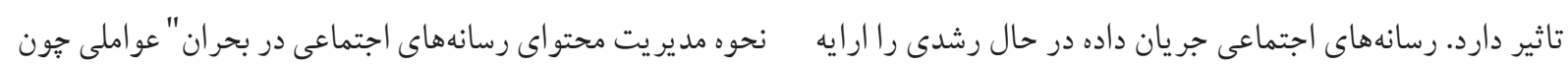

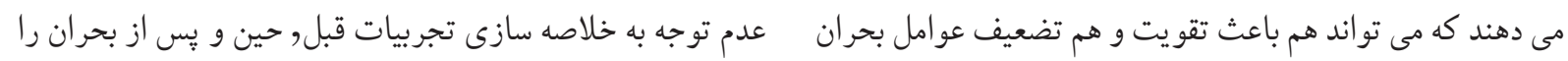

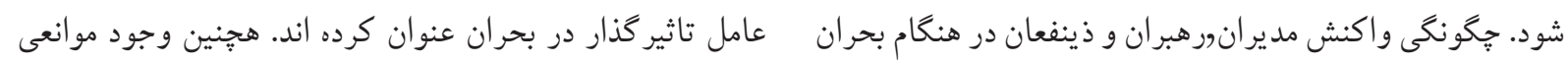

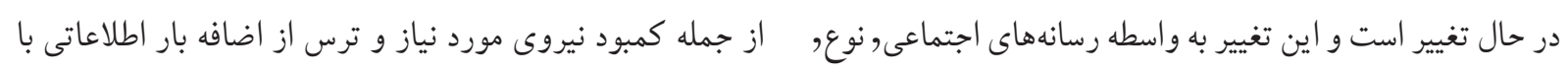

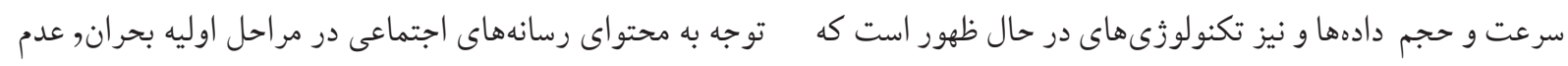


توجه به ايجاد اعتماد, در زمانى, هم آوايى و ايجاد معناى همزمان در رسانههاى اجتماعى را راهكار مديريت بحران عنوان نموده اند.

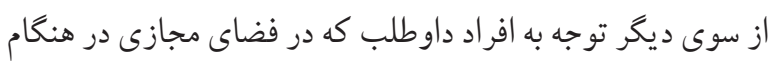

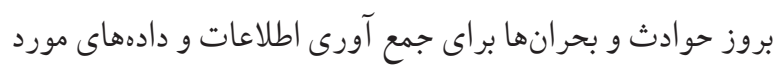

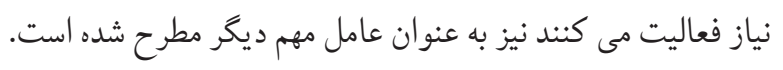
توضيحات تكميلى در جدول شماره إدرج شده است.

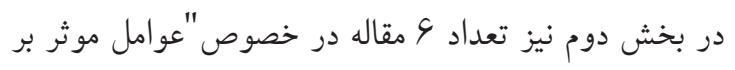

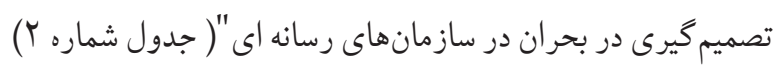

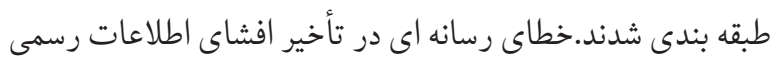

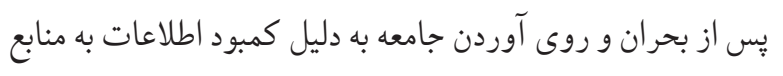

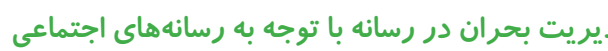

توجه به جريان اطلاعات در رسانههاى اجتماعى در شرايط بحران, خلأ اطلاعات در زمان بحران در رسانههاى اجتماعى, عدم استفاده از رسانههاى اجتماعى در بحرانها به دليل عدم اعتماد به اطلاعات

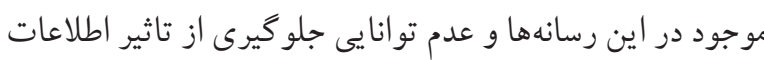

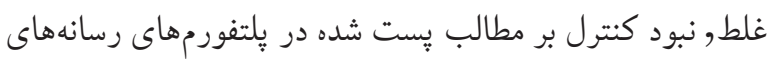

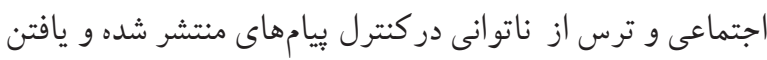

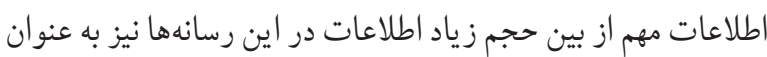

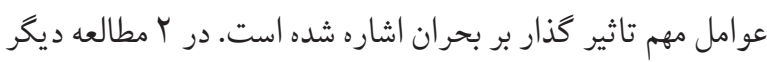

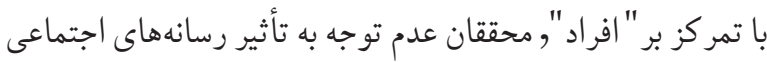

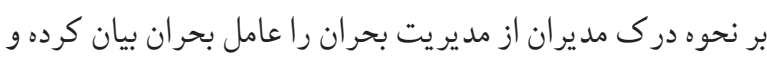

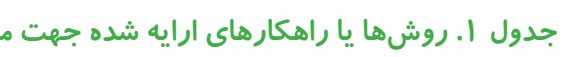

\begin{tabular}{|c|c|c|c|c|}
\hline روش يا راهكار ارايه شده جهت مديريت بحران & عامل بحران/عامل تاثير كذار در بحران & c & عنوان مقاله & 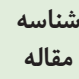 \\
\hline 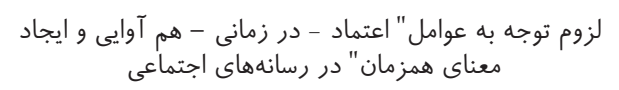 & 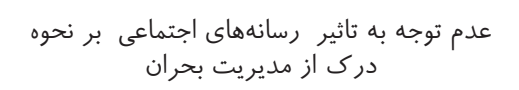 & $\frac{2}{2}$ & Carfagno KA. (13) & 1 \\
\hline 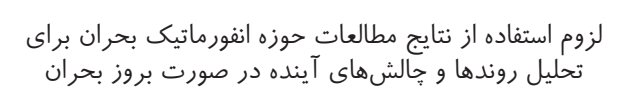 & عدم توجه به خلاصه سازى تجربيات قبل, حين و & $\frac{1}{2}$ & Reuter C(14) & r \\
\hline استفاده از داوطلبان مجازى در حوادث و بحرانها براى تهيه & 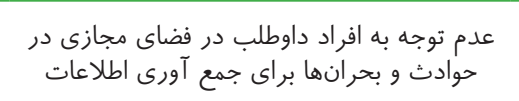 & $\leq$ & Anderson J (15) & r \\
\hline 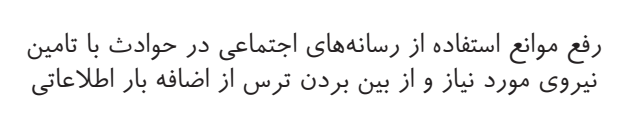 & 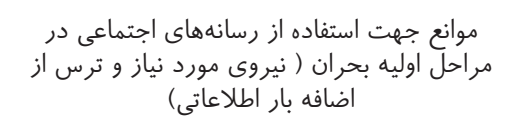 & $\leq$ & Plotnick L (16) & r \\
\hline 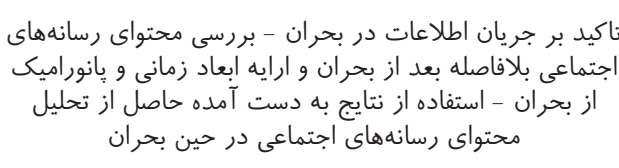 & عدم توجه به جريان اطلاعات در شرايط بحران & $\div$ & $\begin{array}{l}\text { Chaturvedi A, } \\
\text { (17) }\end{array}$ & $\Delta$ \\
\hline 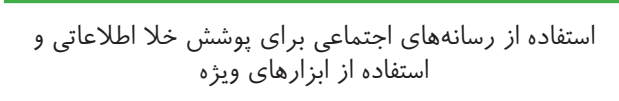 & خلا اطلاعات در زمان بحران در رسانههاى & $\geqq$ & Laudy C (18) & 4 \\
\hline 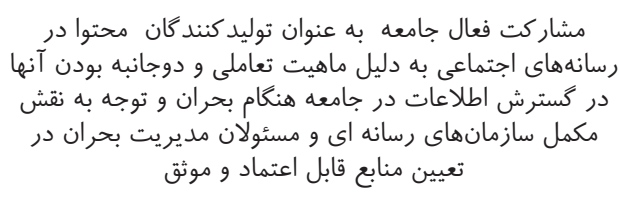 & 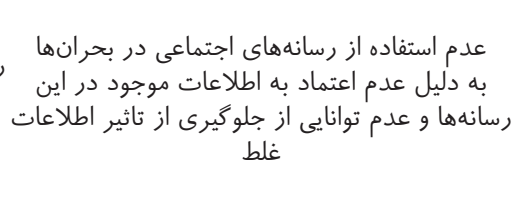 & $\frac{2}{2}$ & Flew T (19) & $\checkmark$ \\
\hline 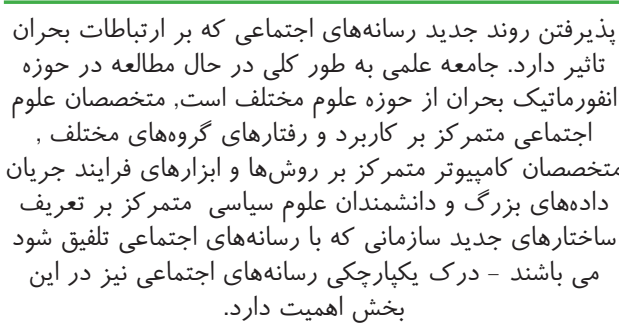 & 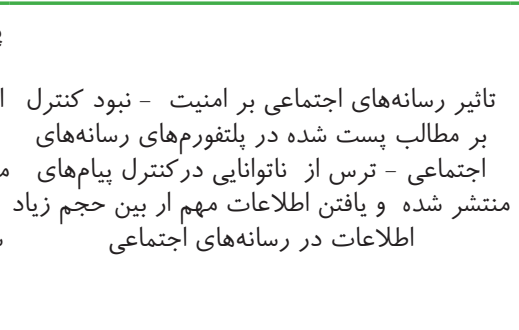 & $\dot{\bar{\sigma}}$ & $\begin{array}{l}\text { J. Wyboa1, F. } \\
\text { Fogelman--Souliéb } \\
\text { C. Gouttasc E. } \\
\text { Freyssinetd, P. } \\
\text { Lionse(5) }\end{array}$ & $\wedge$ \\
\hline
\end{tabular}


خبرى كمتر معتبر و موثق در مطالعات به عنوان عامل تاثير گذار در

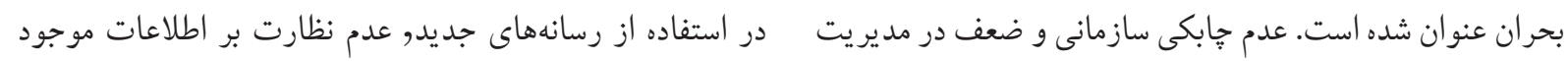

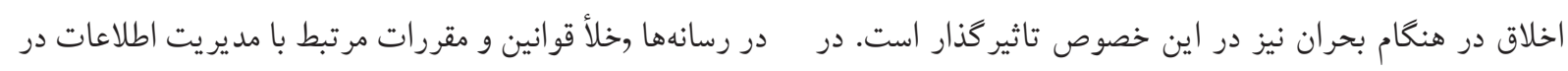

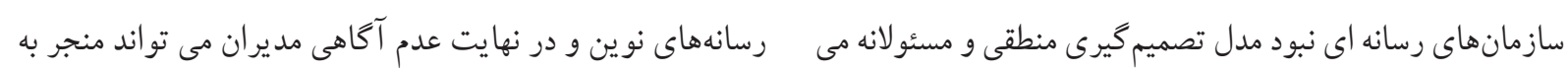

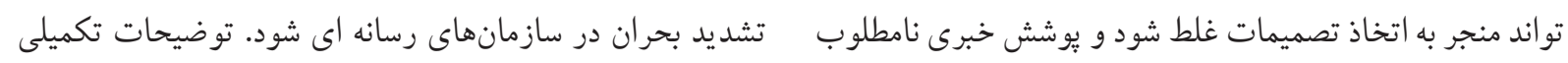

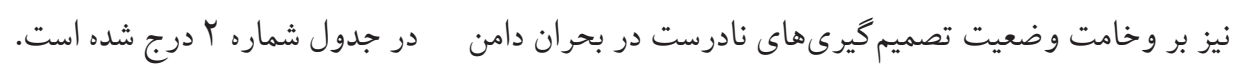

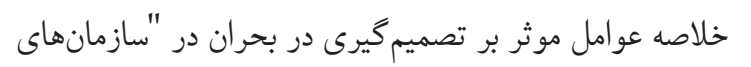

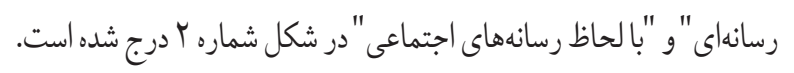

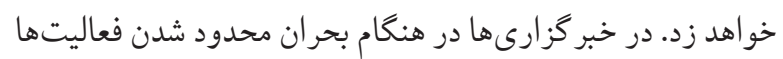

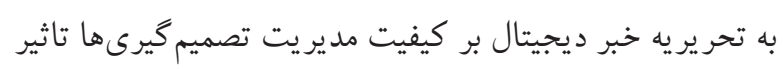

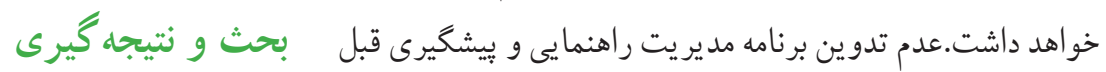

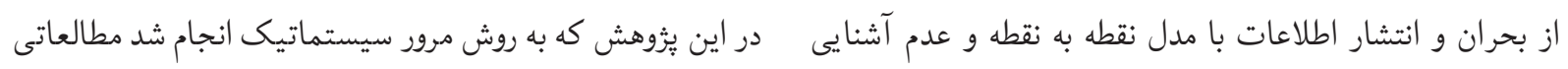
جدول r.: روشها يا راهكارهاى ارايه شده جهت مديريت بحران در رسانه

مقاسه $\quad$ مقاله

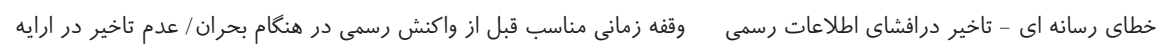

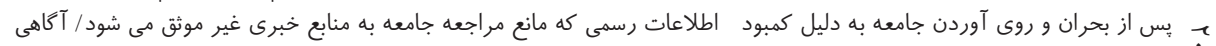

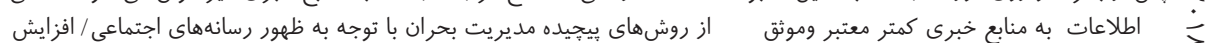

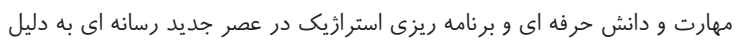

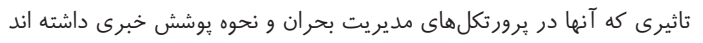

\begin{tabular}{|c|c|c|c|c|}
\hline آموزش خابكى و مديريت اخلاق در سازمانهاى رسانه در هنكام بحران & 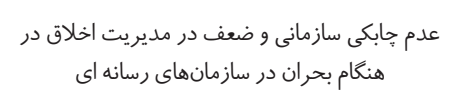 & $\dot{\grave{r}}$ & $\begin{array}{l}\text { Ahmadzadeh } \\
\text { Araji S (23) }\end{array}$ & 1. \\
\hline 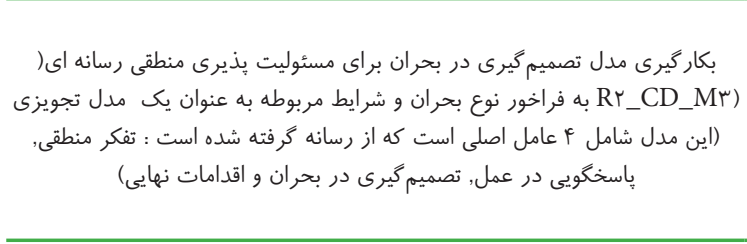 & 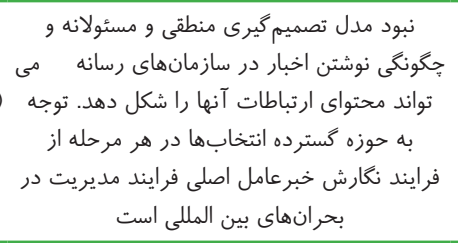 & $\ddot{\vdots}$ & $\begin{array}{l}\text { Abdel Fattah } \\
\qquad \mathrm{M}(29)\end{array}$ & 11 \\
\hline 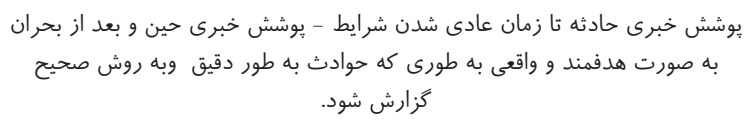 & نحوه اطلاع رسانى در حوادث طبيعى & $\dot{\vdots}$ & $\begin{array}{l}\text { Ghassabi F, } \\
\text { (26) }\end{array}$ & Ir \\
\hline ارجعيت تحريريه خبر سنتى ومتمركز نسبت به تحريريه خبر ديجيتال در مديريت & 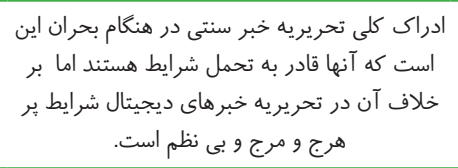 & $\ddot{\vdots}$ & Olsson E-K (28) & Ir \\
\hline 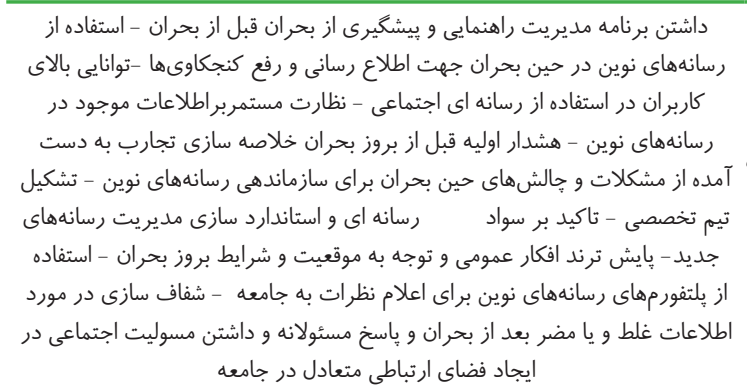 & 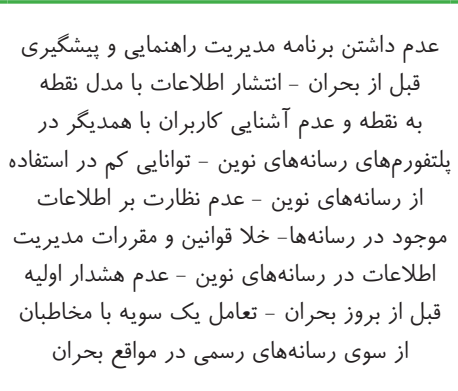 & $\dot{r}$ & Liu X (24) & $1 f$ \\
\hline
\end{tabular}


كه به موضوع "تصميم گيرى در بحران در سازمانهاى رسانه اى" "يرداخته بودند مورد بررسى قرارگرفت.يس از انجام جستجو بر مبناى استراتزى هاى تعريف شدهو بروسى كيفى مطالعات تحليل بودرد برديل

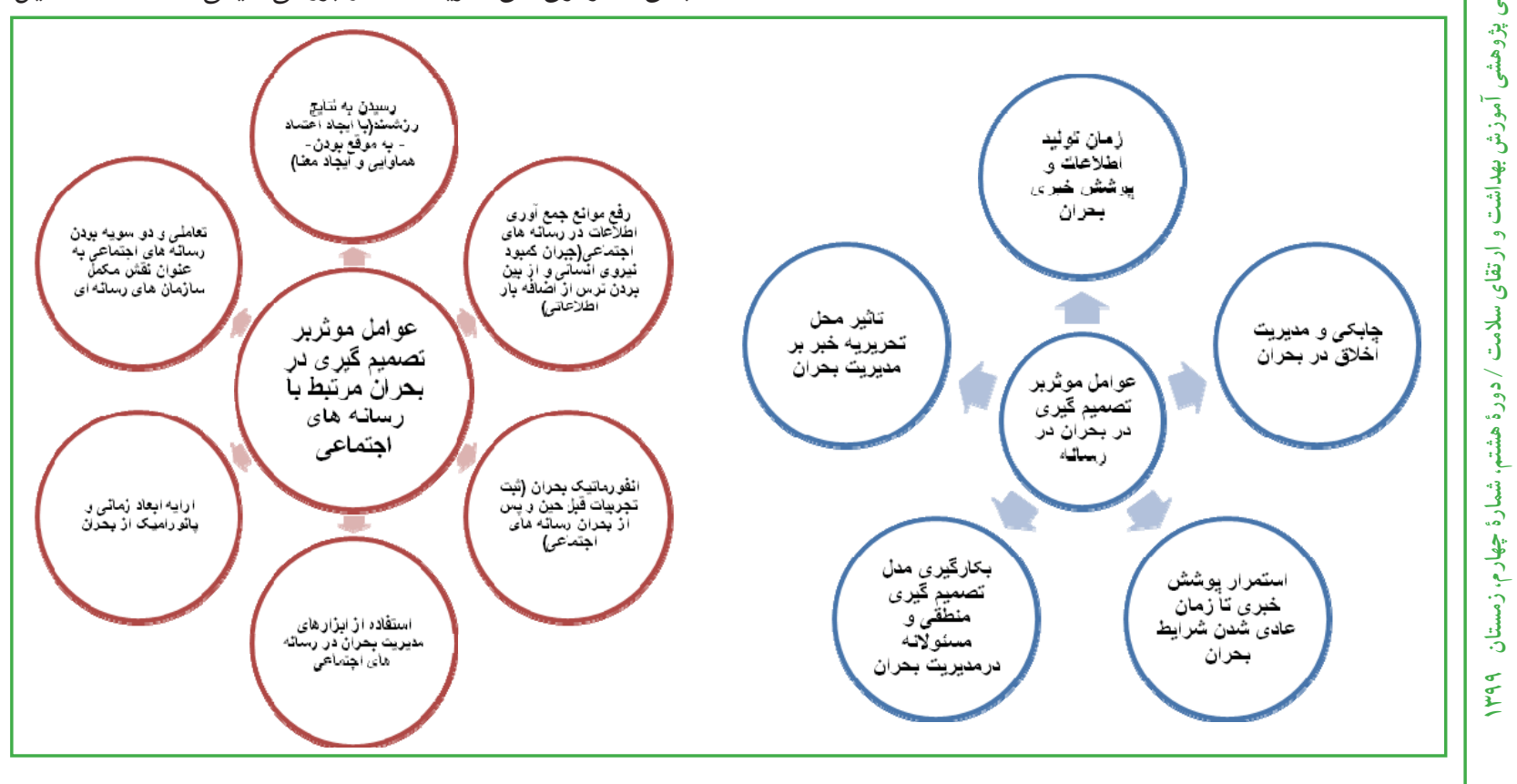

شكل r. خلاصه عوامل موثر بر تصميم يَيرى در بحران در "سازمانهاى رسانه اى" و "با لحاظ رسانههاى اجتماعى"

نهايى بر روى fl إمقاله كه تماهى آنها به زبان انحليسى بودند انجام

ديكر به بحران هاى جارى و حل و فصل آن ها مربوط مى شود.

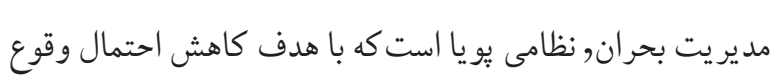

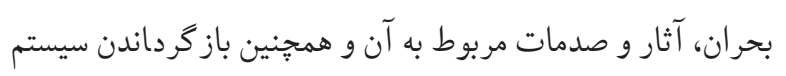

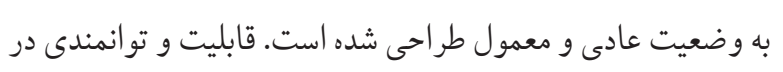

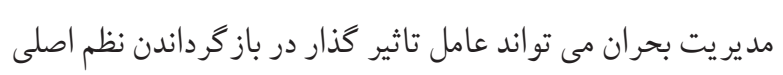

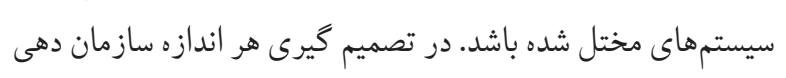

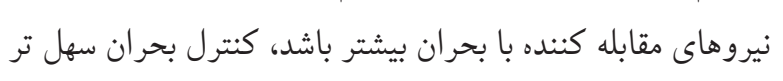

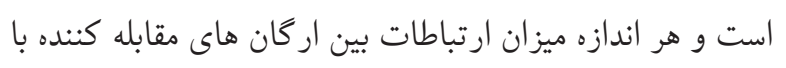

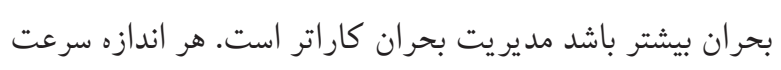

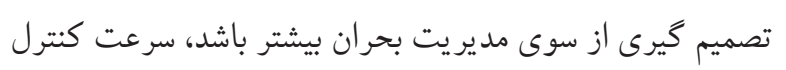

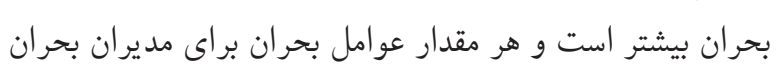

آشناتر و شناخته شده تر باشند، كنترل نيز سهل تر است (1 ال).

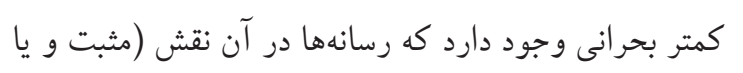

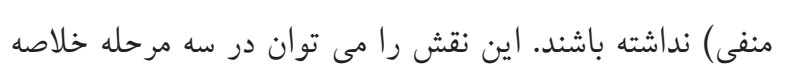

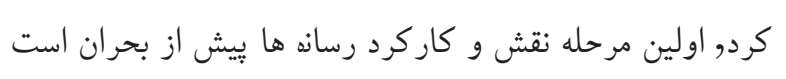

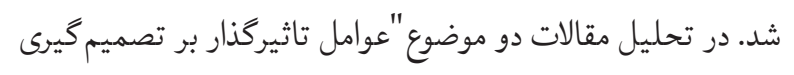

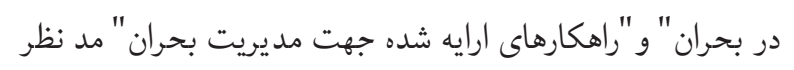
قرار كرفت. در تعريف بحران مى توان كفت كه بحران عبارت

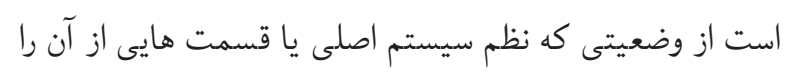

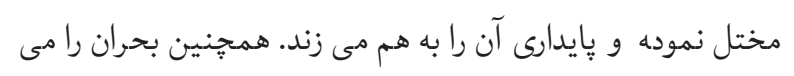

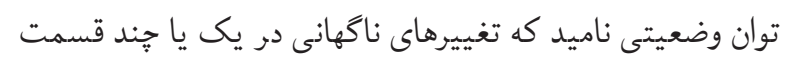

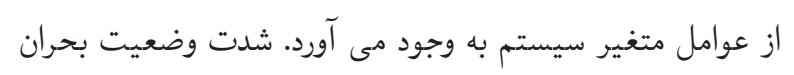
ها بستخى به عوامل تشديد كننده يا عناصر كاهش دهنده بحران

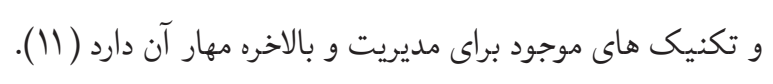

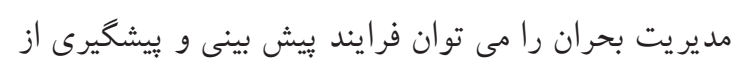

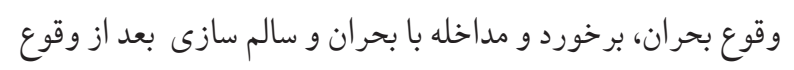

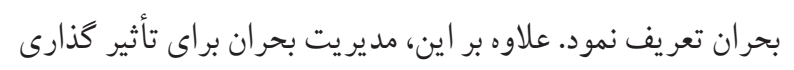

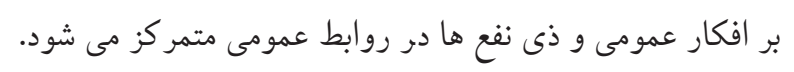

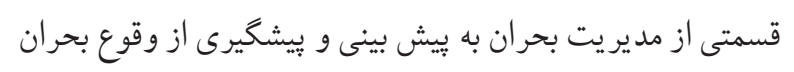

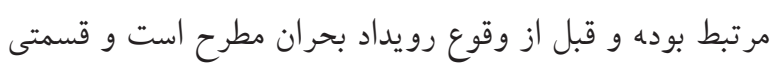


و وسايل مختلف ارتباطى از جمله رسانه هاى گروهى سعى مى شود

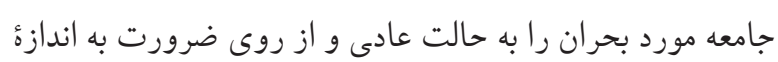
مشابه حالت بيش از بحران بركرداند( (1) ).

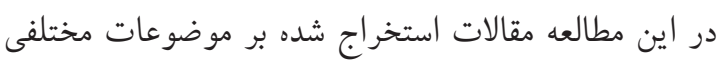

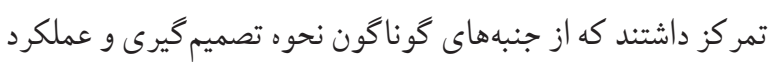

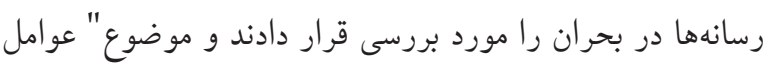

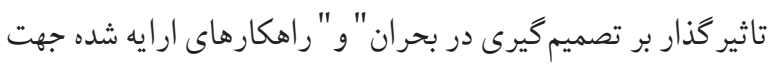

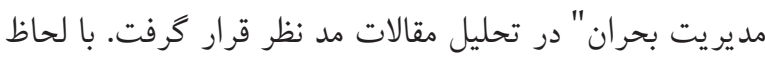

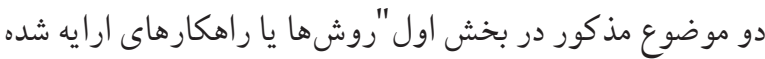

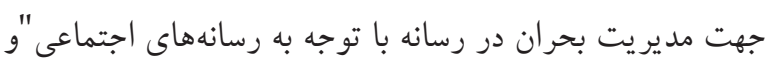

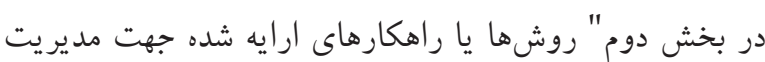
بحران در رسانهها"بررسى شد. بخش اول : روشها يا راهكارهاى ارايه شده جهت مدئ بديريت

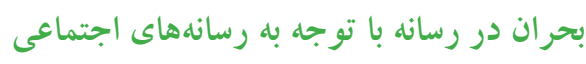
رسيدن به نتايج ارزشمند با ايجاد اعتماد, به موقع بودن, هم آوايى بـ رساي و ايجاد معنا در مطالعه اي كه توسط Carfagno KA (r (1) انجام شد بيان شد كه عدم توجه به تأثير رسانهاى اجتماعى بر نحوه درى از

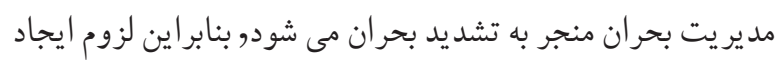

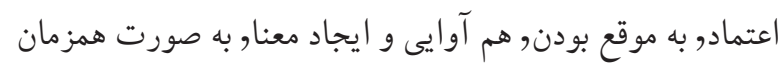

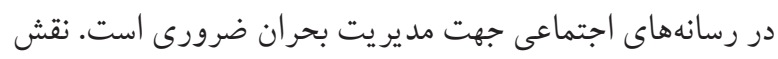

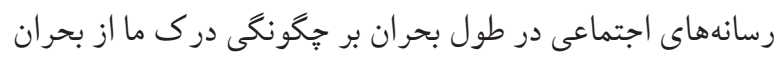

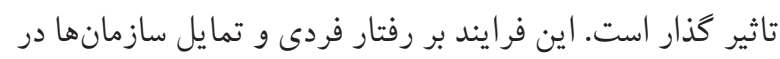

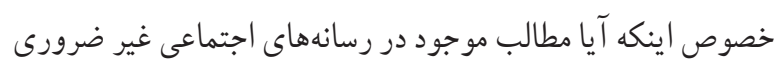

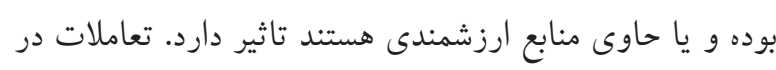

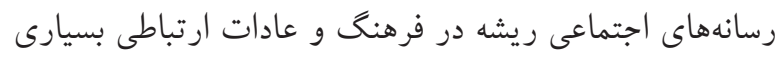

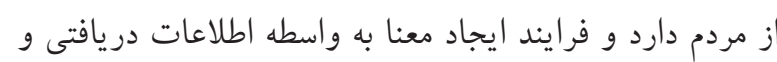

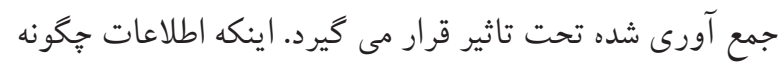

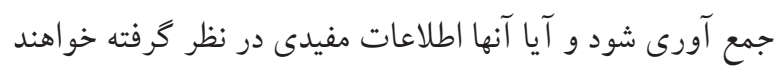

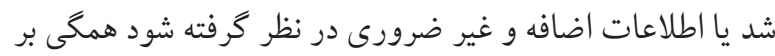
تصميمات مهم موثر خو اهد بود (1)
كه بسيار با اهميت است. برنامـه ريـزان بــهـ آموزش نيروها براى

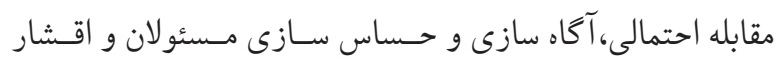

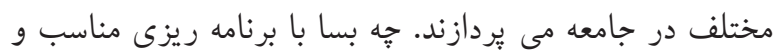

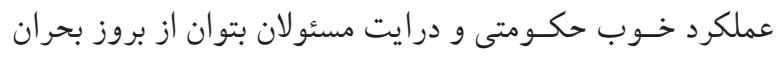

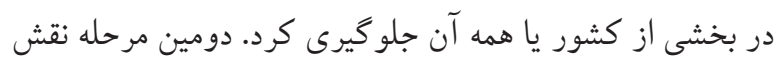

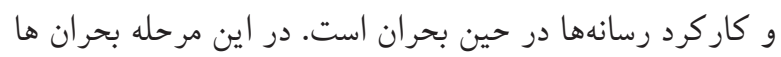

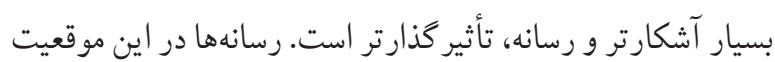

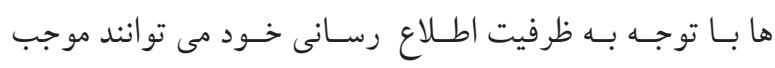

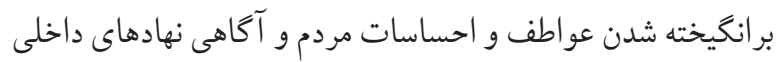
و بين المللى شوند. بيشتر ين تحقيقات انجام شده درباره نقش رسانه ها در بحران ها مربسوط به فجايع طبيعى و در اين مر حله بوده است.

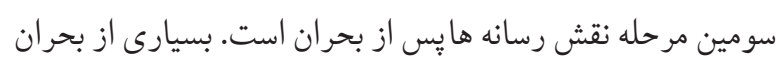

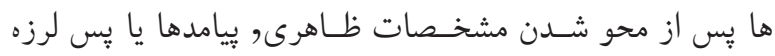
هاى ديكرى به دنبال دارند كه آنها را مى توان به دو دسته تقسيم

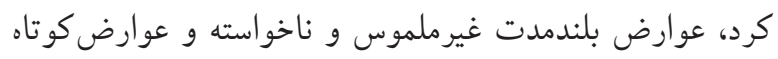

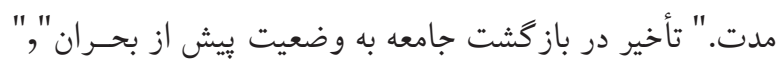

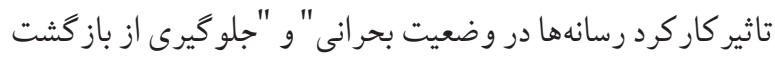

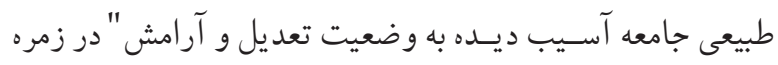

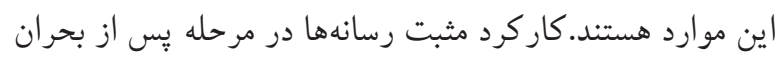

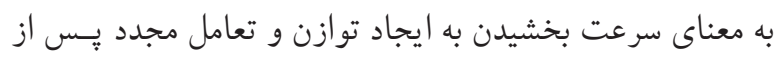
فاجعـه طبيعى و جلو گيرى از بحران مضاعف است. اولين مرحله

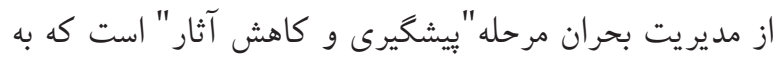

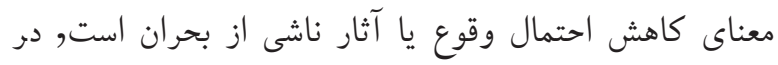
واقع اين مرحله مصداق ضرب المثل (ييش گيرى بهتر از درمان

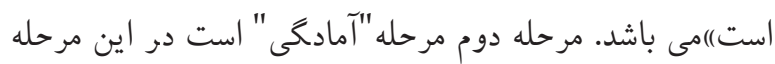

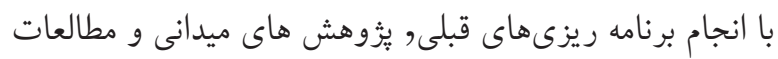

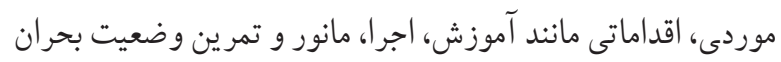
در شرايط مختلف مى تواند مؤثر واقع شود.در مرحله بعد يعنى اجري

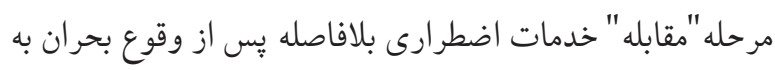
خصوص اطلاع رسانى به موقع و كنترل ارتباطات درون و برون

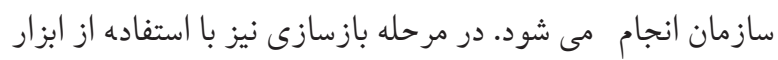


سيتامبر افزايش پيدا كرد و بسيارى از تحقيقات بر كاربرد ICT و

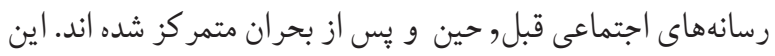

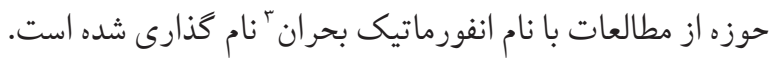

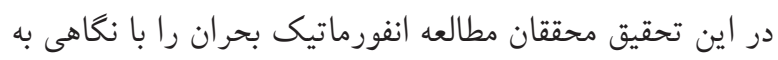

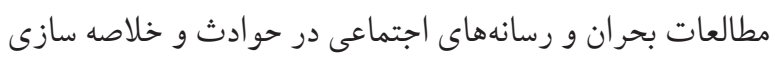
انواع مطالعات انجام شده در حوزه انفورماتيك بحران انجام داده اندو در نهايت دستارودهاى به دست آمده براى روندهار ديد ماهها

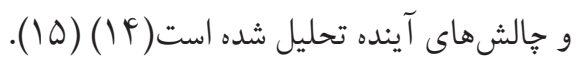
رفع موانع جمع آورى اطلاعات در رسانههاى اجتماعى با جبران كمبود نيروى انسانى و از بين بردن ترس از اضافه بار اطلاعاتى

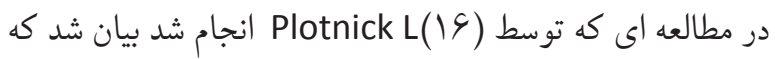
اكرجه رسانههاى اجتماعى با آحاهى بخشى در مر احل اوليه بحران

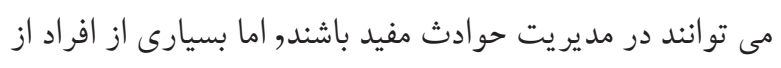

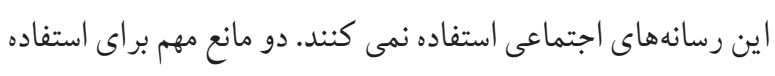

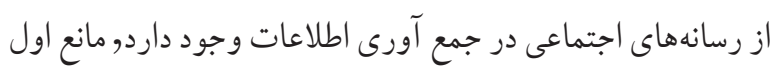
كمبود نيروى انسانى و مانع دوم ترس از اضافه بار اطلاعاتى است دون.

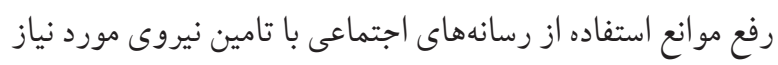

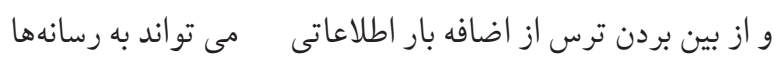

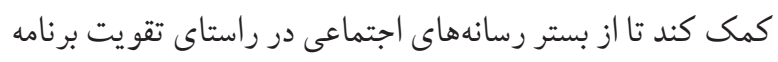

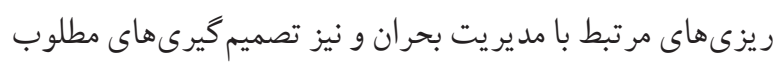

استفاده نما يند(19) - (19).

ماهيت تعاملى و دو سو يه بودن رسانههاى اجتماعى لمانى

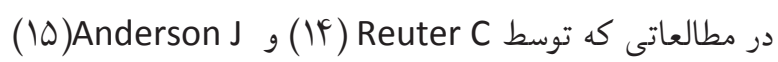
انجام شد بيان شده است كه رسانهاى اجتماعى نسبت به رسانههاى توسط

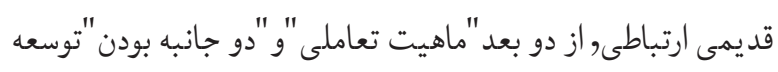

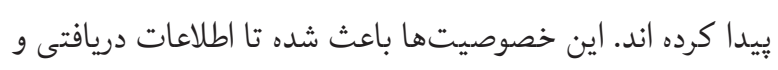
بيامها در جامعه كسترش پيدا كنند. رسانههاى اجتماعى تكميل كننده رسانههاى ارتباطى سنتى مانند رسانههاى خبرى هستند اما

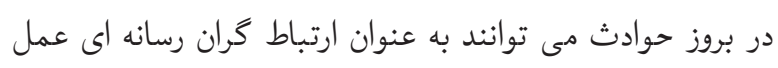

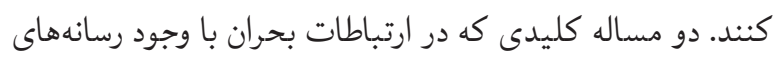

3. crisis informatic
رسانهاى اجتماعى جريان داده در حال رشدى را ارايه مى

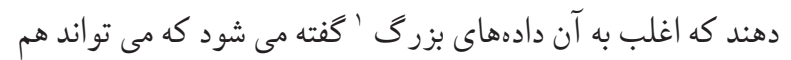

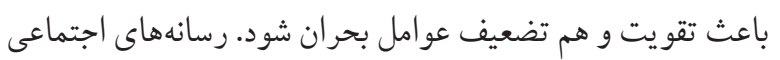
بخش مهم ايجاد معنا را تغيير مى دهند و به دليل گسترد مَى منابع

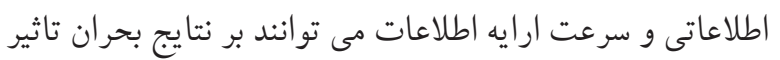

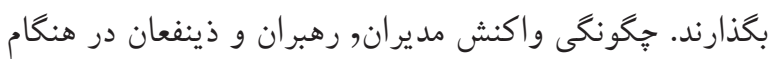

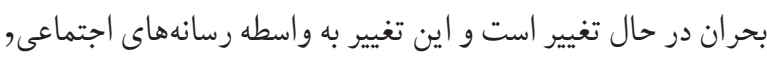

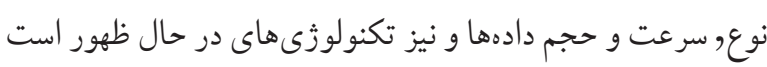

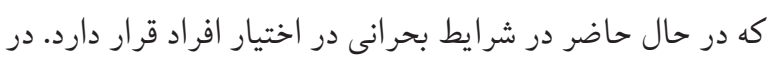

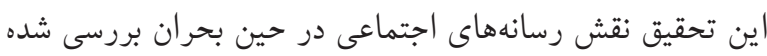

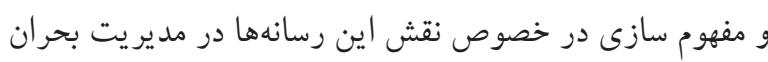
با روش جديد بررسى شده است. مفهوم سازى عبارت" اثر اقدام

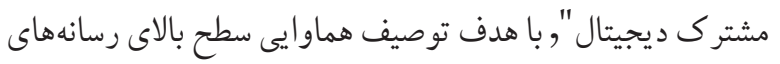
اجتماعى براى حمايت از اقدامات در مديريت بحران مطرح شده

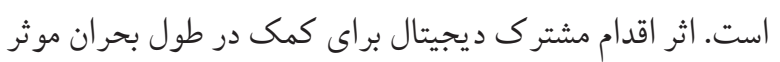

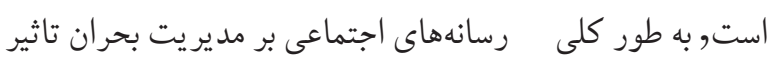
كذار هستند و براى دستيابى به نتايج ارزشمند به واسطه استفاده

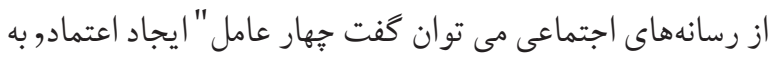

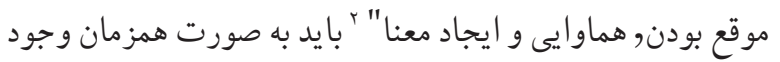

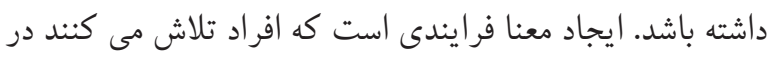

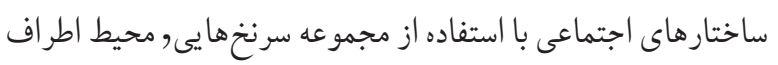

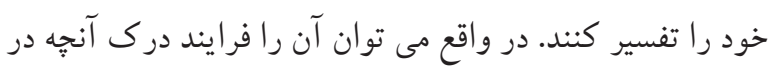

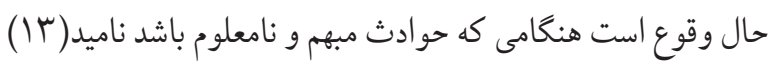

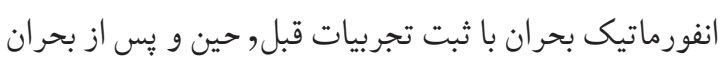

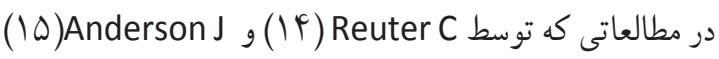
انجام شد بيان شده است كه عدم توجه به خلاصه سازى تجربيات

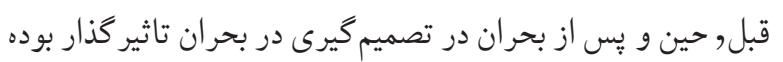

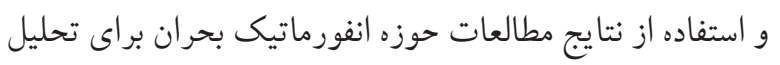
روندها و جالشهاى آينده ضرورى است. استفاده از رسانههاى

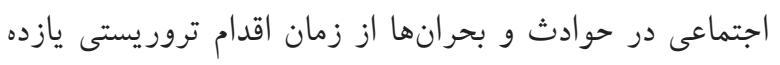


r+1
از بين ييامها ارايه مى كند و تحليل معنايى يُيامهاى رسانهایى اجتماعى را براى كاهش خطر اضافه بار اطلاعاتى در مركز عمليات انجام مى دهد و" ابزار تحليل معنايى انتشار اطلاعات" (IE-SIF)

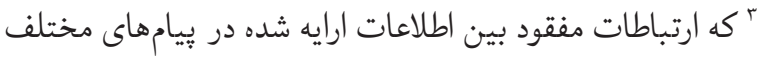

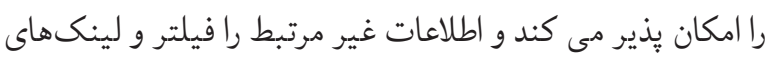

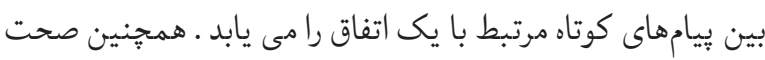

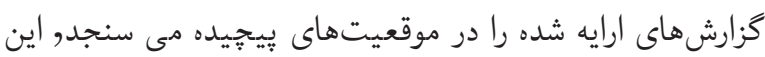

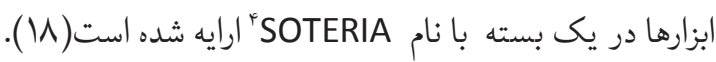
روندهاى جديد رسانهاى اجتماعى موثر بر بحر بان اندان

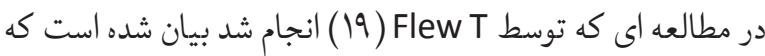
رسانههاى اجتماعى امروزه بخشى از سيستمهاى سازمانى مديريت

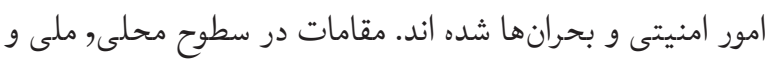
منطقه اى بيش از يِيش اين رسانها را در فرايندهاى خود قرار مى إنى

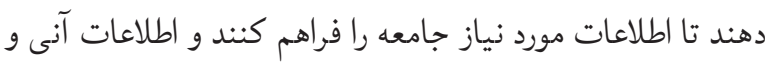
فورى در مورد آنجه در حال وقوع است بدست بياورند. اما استفاده

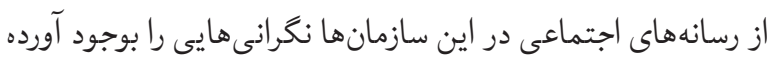

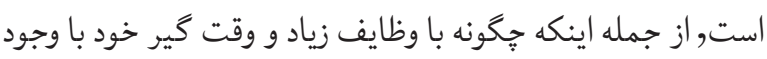
اين موضوع كنار بيايند؟ جُكونه از كاربرد نادرست رسانهها خوددارى

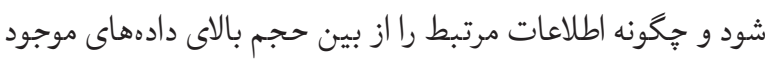

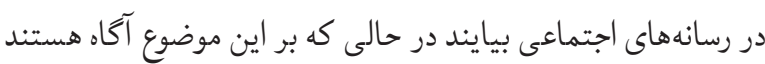

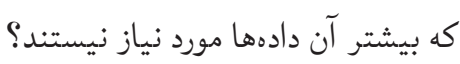
به طور كلى جامعه علمى روى اين موضوع از حوزه علوم مختلف دانف

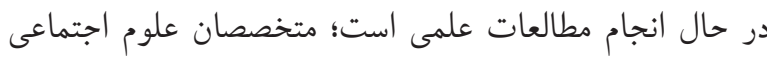

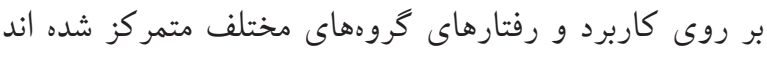
متخصصان علوم كامييوتر روشها و ابزارهاى شناخت فرايند جريان

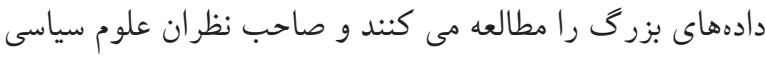

3. IE-SIF : the semantic information fusion and analysis "ابزار تحليل معنايى انتشار اطلاعات")( IE-SIF) كه اطلاعات غير مرتبط را فيلتر

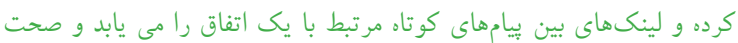
4. SOTERIA :toolbox

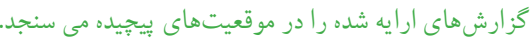
بسته ابزار SOTERIA به عنوان يك مجموعه به كاربران ارايه شده است. بسيارى از كشورها اين بسته را آزمايش كرده و استفاده مى كنند و بسيار از آن استقبال كرده اند.
اجتماعى مطرح مى شود" قدرت اعتماد و هماهنكى" است. "قدرت

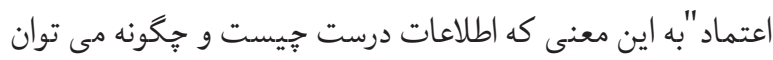
از تأثير اطلاعات غلط جلوكيرى كردو وهماهنكى"به اين مفهوم كه

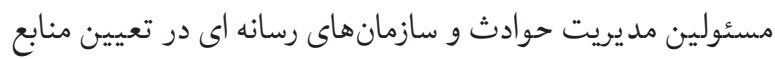

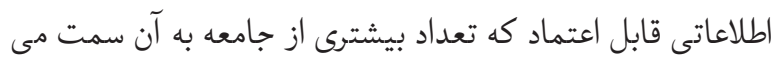
روند نقش مكمل دارند. همجنين مشخص شد كه عامل كليدى و مهم كاربرد رسانهاى اجتماعى اثر بخش, مشاركت فعال جامعه به عنوان توليدكنند كان رسانه اي محتواهاى مرتبط است. در نتيجه مى توان كفت استفاده از رسانهاى اجتماعى به دليل "ماهيت تعاملى و دوسويه بودن براى گسترش اطلاعات در جامعه در هنكام بحران","توجه به نقش مكمل سازمانهاى رسانه اى و مسئولين

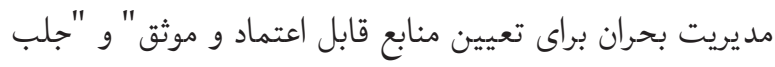
مشاركت فعال جامعه به عنوان توليدكنند كان محتواى مرتبط رسانه

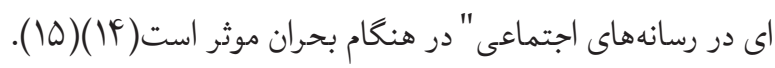

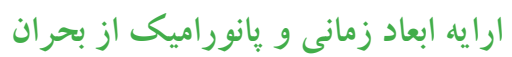
در مطالعه اي كه توسط Chaturvedi A, (IV) انجام شد بيان شده است كه "بررسى محتواى رسانهاي اجتماعى بلافاصله بعد از بحران",

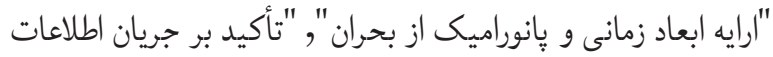

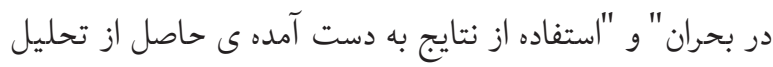

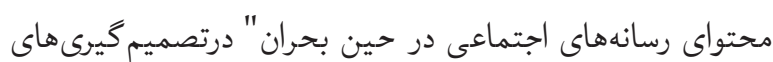

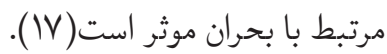

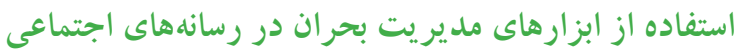

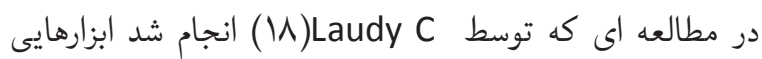
براى مديريت بحران درسه بخش ارايه كرديد," ابزار تحليل

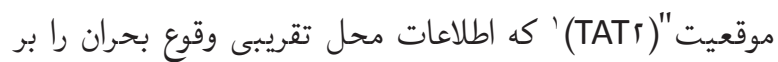

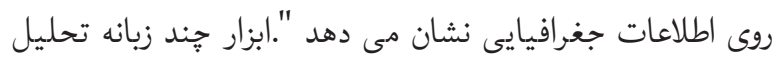

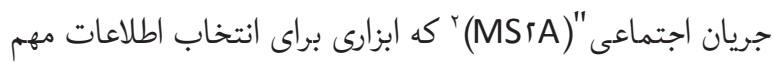

1. TAT2 : the test analysis tool locator "ابزار تحليل موقعيت" (TATr)ابزارى است كه اطلاعات محل تقر يبى را بر روى

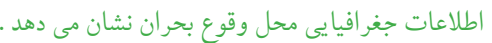
2. MS2A : the multilingual social stresm analysis "ابزار جند زبانه تحليل جريان اجتماعى" (MSYA) تحليل معنايى ييام هاى رسانه هاى

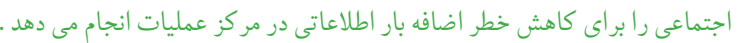


نتيجه خطاى رسانه اي خواهد شد. تاخير در افشاى اطلاعات رسمى يس از بحران و روى آوردن جامعه به منابع خبرى كمتر معتبر و و موثق به دليل كمبود اطلاعات اجتناب نايذير خواهد بود( (9). وقفه زمانى مناسب قبل از واكنش رسمى در هنگحام بحران, عدم تأخير

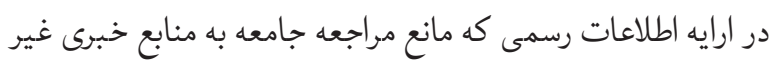

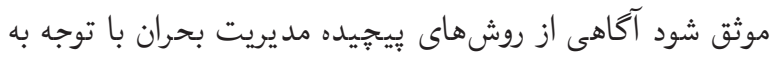
ظهور رسانههاى اجتماعى, افزايش مهارت و دانش حرفه اى و برنامه ريزى استراتزيك در عصر جديد رسانه اي به دليل تأثير آنها در

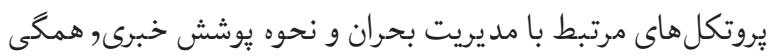

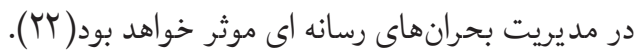

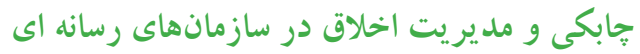
در يُزوهشى كه توسط Ahmadzadeh Araji S انجام شد بيان شده

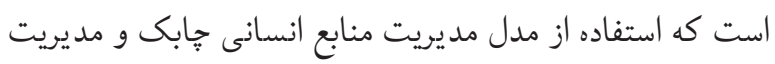
اخلاق در حين بحران در سازمانهاى رسانه ایى عوامل مهمى در مدرئ

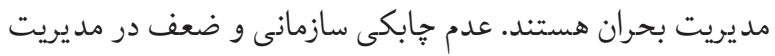
اخلاق در هنكام بحران مى تواند از عوامل تشديد كننده بحران

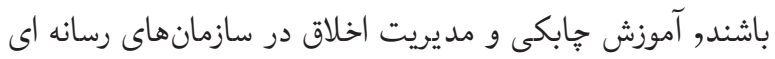

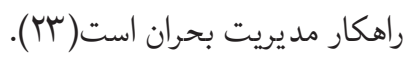
بكار گيرى مدل تصميم گيرى منطقى و مسئو لانه. در مطالعه اى كه توسط Abdel Fattah M انجام شد بيان شده است كه استفاده از مدل تصميم گيرى منطقى و مسئولانه مى تواند محتواى ارتباطات در رسانهها را شكل دهد. توجه به حوزه گسترده انتخابها در هر مرحله از فرايند نكارش خبر, عامل اصلى در فرايند مديريت در بحرانها است. بكاركيرى مدل" تصميم گيرى در بحران

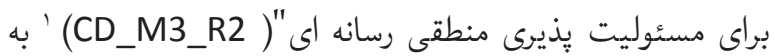
فراخور نوع بحران و شرايط مربوطه مى تواند به عنوان يك مدل مل مائ

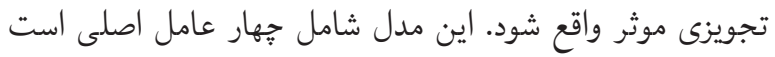

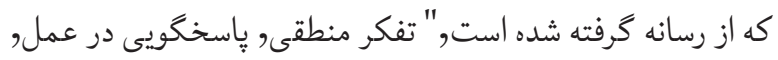

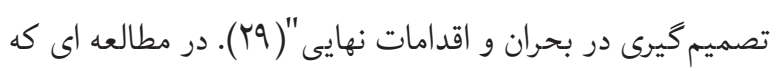
توسط Liu X انجام شد بيان شده است كه عوامل زير همخى بر نوع

1. CD_M3_R2 : Crisis Decision-Making Model for Media Rational Responsibility
تعريف ساختارهاى جديد سازمانى را كه با رسانههاى اجتماعى تلفيق شده مطالعه مى كنند. محققان حوزههاى مختلف بايد براى سياست گذاران و مسئولان و فعالان پڤتوانه علمى قوى ارايه كنند

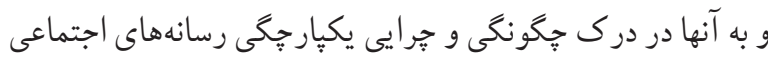
در فعاليتهاى مربوط به امنيت و حفاظت كمك كنند. نبود كنترل

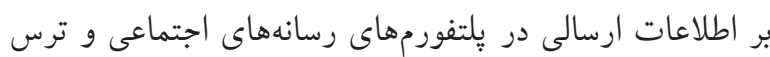

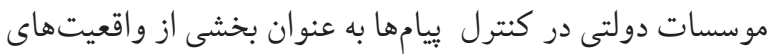

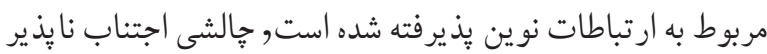

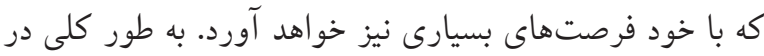

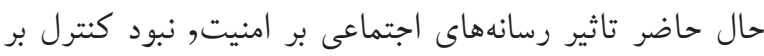

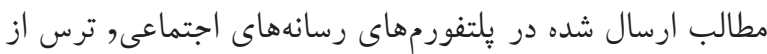

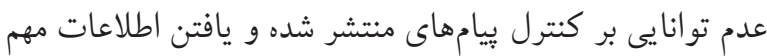
زز ميان حجم زياد اطلاعات در رسانهاى اجتماعى مطرح است.

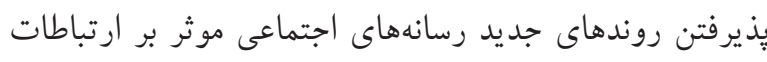

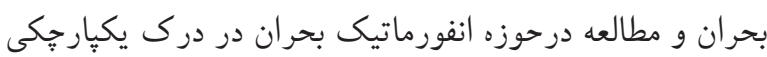
رسانههاى اجتماعى بحران تاثير گذار خواهد بود(9 (1).

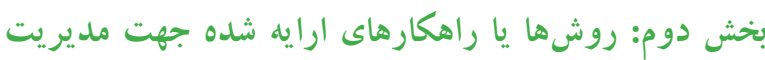
بحران در رسانهها زمان تو ليد محتوا (T• DG Pintér

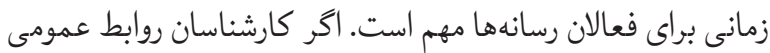
و ديخر افرادى كه در كارزارهاى اطلاعاتى كار مى كنند بدانند جقدر طول مى كشد تا اهميت موضوعى را در وجدان عمومى تقويت

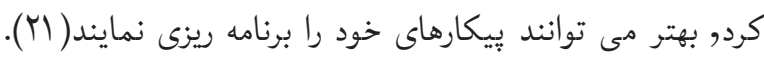
زمان توليد محتواى مرتبط با بحران در فضاى مجازى مى تواند

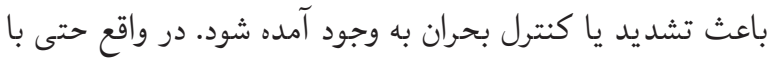

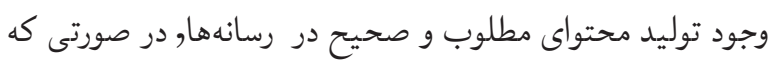

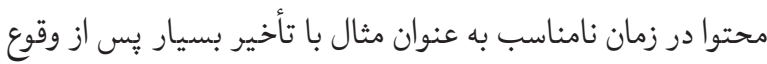

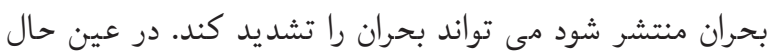

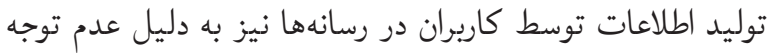
به صحت منابع خبرى منجر به اختلاف در اطلاعات ارايه شده و در لري 
شد) شهO). با توجه به موارد اشاره شده در جايى كه ميزان خطر پذيرى

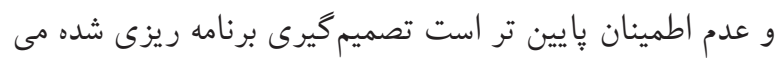

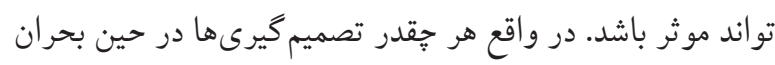

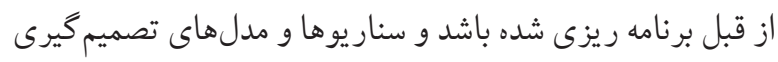

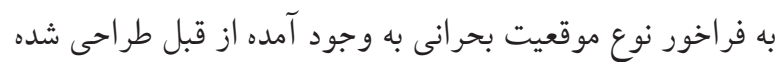

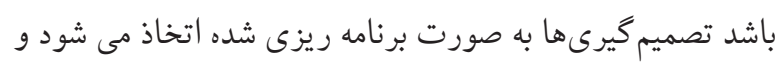
از تبعات منفى بحرانها جلو گيرى خو اهد شد.

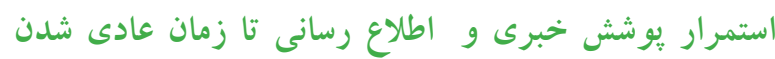
شرايط بحر انى در مطالعه اى كه توسط Ghassabi F. انجام شد عنوان شده است كه در هنگام بروز بحرانهاى مختلف, نوع يوشش خبرى موضوع

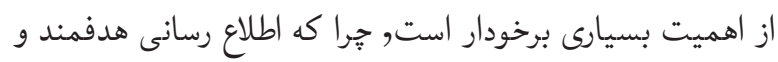

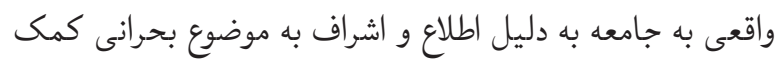

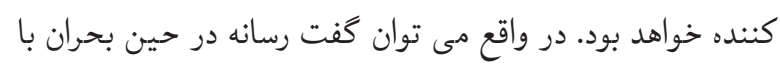
برجسته سازى موضوع بحرانى, يوشش خبرى و اطلاع رسانى صحيح

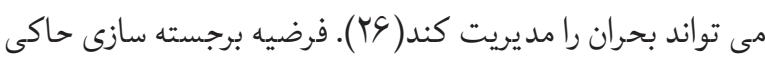

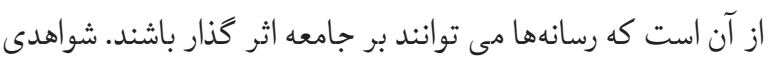

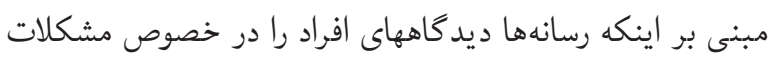
مهمى كه جامعه با آنها مواجه است شكل مى دهند وجود دارد. ممكن دئن

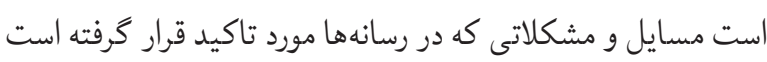

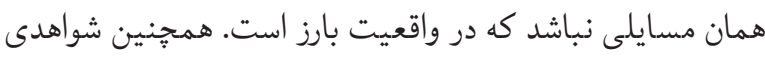

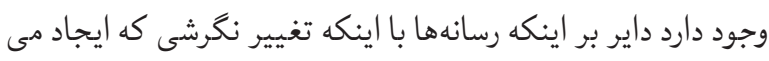

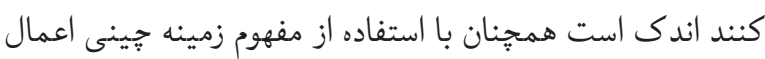

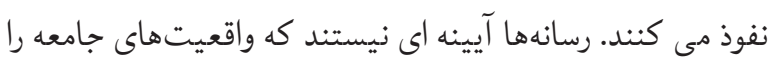
جنان كه هستند منعكس كنند, مطبوعات مانند نور افكن هستند و هنگام نورافشانى ممكن است تحت تاثير "خروههايى كه منافع

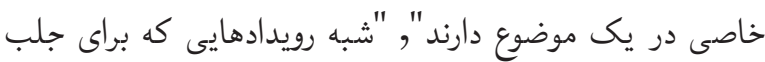
توجه آفريده شده اند"و "عادات خاص روزنامه نغاران" قرار كيرند.

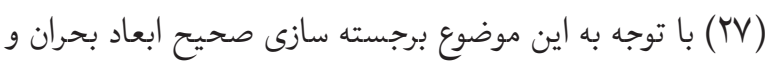

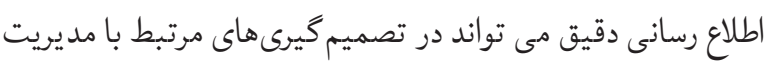
بحران موثر باشد و با جلب توجه جامعه و ايجاد تعاملى دوسويه
تصميم گيرى موثر هستند ,"عدم برنامه ريزى در خصوص مديريت,

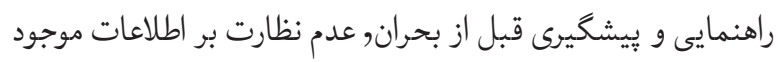

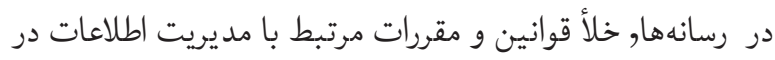
رسانهاى نوين, عدم هشدار اوليه قبل از بروز بحران, تعامل يك سويه با مخاطبان از سوى رسانههاى رسمى در مواقع بحران" (MF). جهت ايجاد فضاى ارتباطى متعادل در جامعه نيز موارد زير مورد توجه قرار گرفته است," توانايى بالاى كاربران در استفاده از رسانه

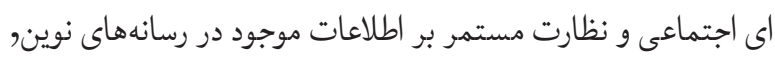

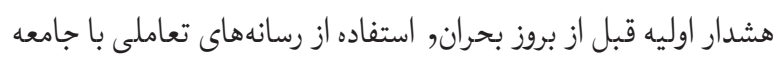
در هنگام بحران, خلاصه سازى تجارب به دست آمده از مشكلات و جالشهاى حين بحران براى سازماندهى رسانهاي نوين, تشكيل تيم تخصصى, تاكيد بر سواد رسانه اى, استاندارد سازى مديريت

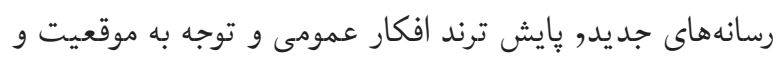

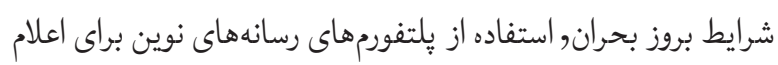

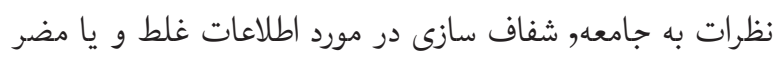
بعد از بحران و پاسخ مسئولانه و داشتن مسئوليت اجتماعى" (YY).

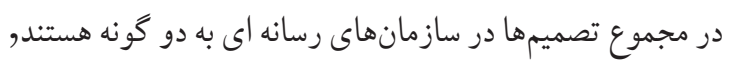
برنامه ريزى شده و برنامه ريزى نشده. تصميم گيرى برنامه ريزى شده

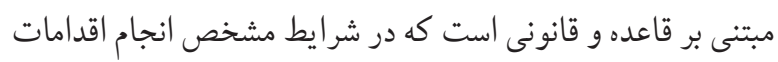
را ميسر مى سازد. در صورتى كه تصميم گيرى برنامه ريزى نشده

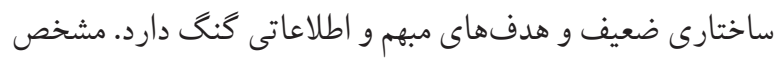
كردن يرداخت ماهانه كار كنان نمونه ایى از تصميم گيرى برنامه مئم ريزى

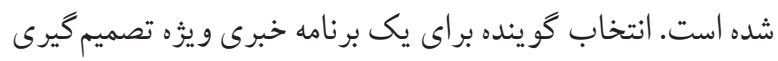

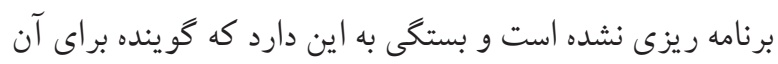
برنامه مناسب تر بوده و جقدر در دسترس است. تشخيص ميان يك تصميم گيرى برنامه ريزى شده و نشده يك مساله مهم است.

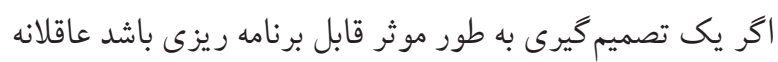

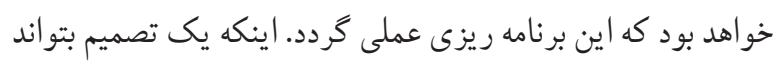

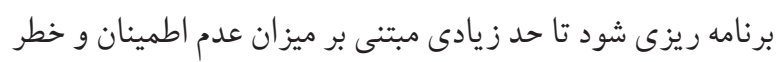

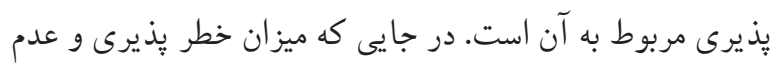

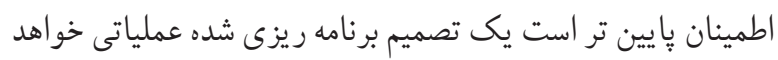


از بيامهاى ارتباطى در رسانها به منظور افزايش سطح بهداشت

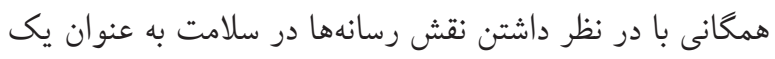

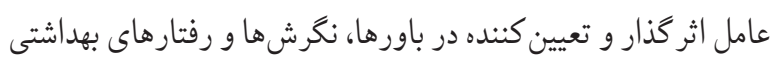

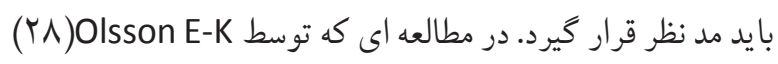

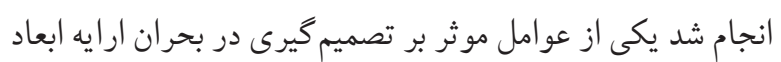

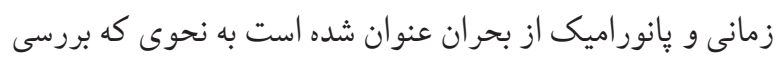

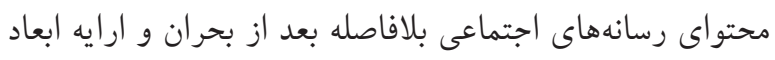

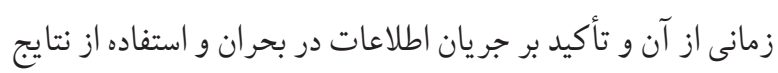
به دست آمده ى حاصل از تحليل محتواى رسانه هاى اجتماعى در اند

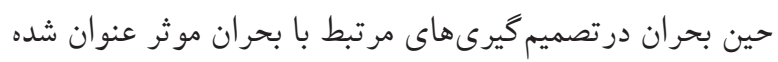

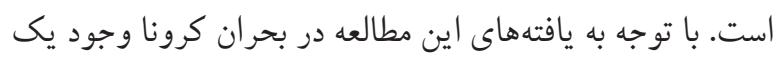

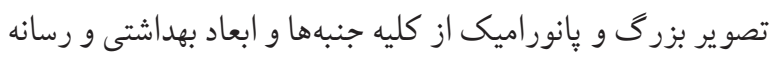

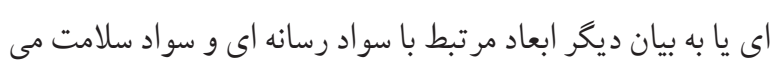
تواند منجر به تصميم گيرى هاى مطلوب تر در نظام سلامت شود.

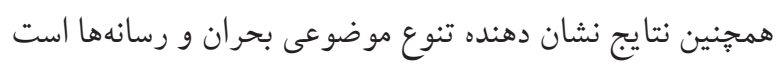

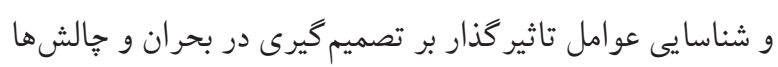

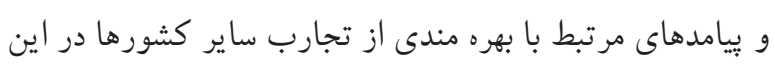
رابطه در ييشرفت اين بخش كمك كننده خواهد بود.

بيشنهادات

بيشنهاد مى شود عوامل موثر بر تصميم گيرى در بحران در رسانهها

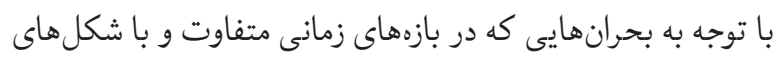
مختلف بروز مى كند با انجام مطالعات ديخرى با ماهيت مرور

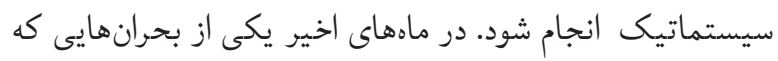

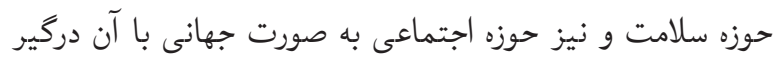

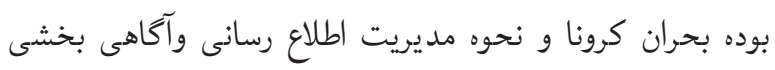

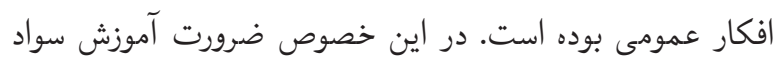
سلامت و ارتقاء سواد رسانه اي مديران حوزه رسانه در هنكام مواجهه با شرايط بحرانى از جمله بحرانهاى حوزه سلامت (ياندمى كرونا) امرى ضرورى است.

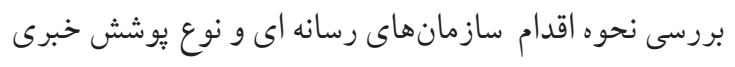
اين بحران مى تواند به عنوان منبع جديدى از اطلاعات و مطالعات
بين رسانه و مردم با دريافت بازخوردها و نظرات از آنها منجر به تصميم گيرى هاى كاربردى ترى شود.

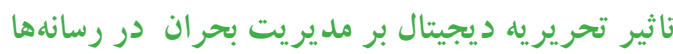
در مطالعه اى كه توسط YN)Olsson E-K) انجام شد بيان شده است كه هر جند در شرايط بحرانى فعاليت به صورت ديجيتال و

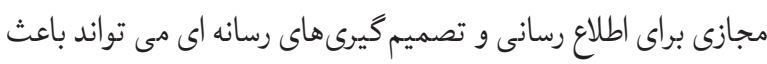
تسريع در امور شود اما با توجه به تحقيقات انجام شده تحريريههاى خبر سنتى در شرايط بحرانى قادر به تحمل شرايط بحرانى به شكل بهترى هستند. به دليل متمركز بودن محل تحريريه تصميم خيرى دئي در خصوص تنظيم اخبار و بوشش خبرى در شرايط بحرانى بسيار موثرتر انجام مى كيرد. به طور كلى در طى اجراى مرور سيستماتيك در تحليل مقالات

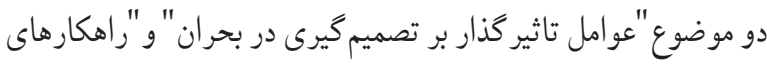

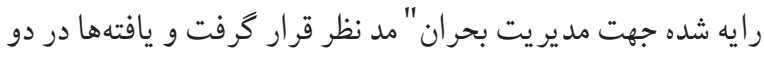

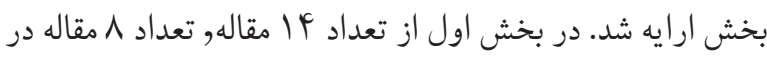

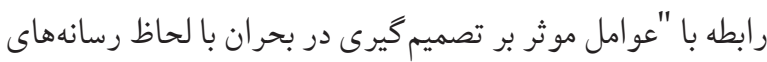

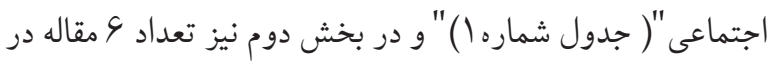

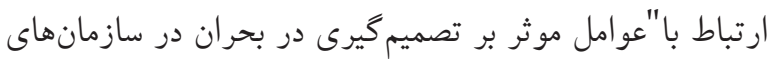

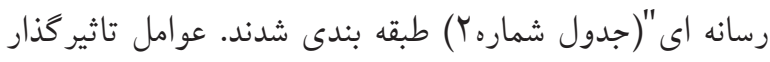

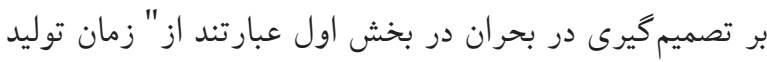

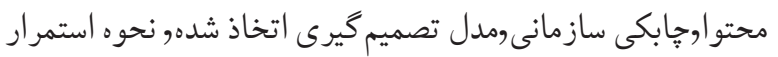
يو شش خبرى در بحرانوتاثير محل وقوع بحران بر مديريت بحران"و

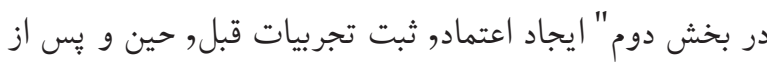

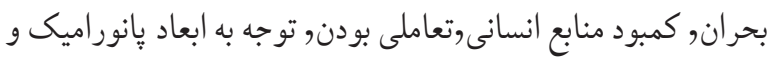

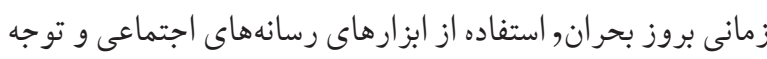
به روندهاى نوين رسانه ايى".

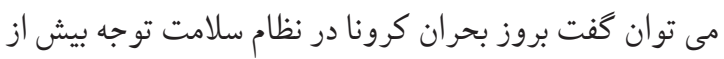

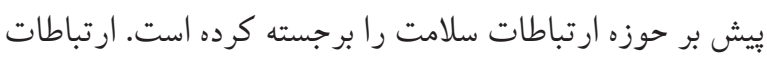

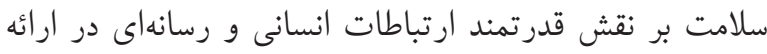
مر اقبت هاى بهداشتى و ارتقاى سطح سلامت تاكيد دارد. جخونكى تأثير ارتباطات بر نحوه ارائه مراقبت هاى بهداشتى و واستى استفاده اقناعى 
سازمانهاى رسانه اي بايد مورد توجه قرار گيرد. همجنين بيشنهاد مى شود در يزوهشهاى آتى اين ابعاد از موضوعات در سطوح و از جنبههاى ديگر مورد بررسى قرار گيرد و با وجود بحران كرونا انجام مطالعات مرتبط با اين بحران و عملكرد رسانهها از جنبه ارتباطات سلامت و سو اد رسانه اى نيز با روش مرور سيستماتيك

$$
\text { و ساير روش هاى مطالعاتى توصيه مى شود . }
$$

\section{References}

1. Rahpeik S. Decision Making Process in crisis and the Role of media. Journal of Communication Research (Pazhoohesh Va Sanjesh).2009; 15 (56): 119-135.

2. Charoghchian Khorasani E, Tavakoly Sany SB, Tehrani H, Doosti H, Peyman N. Review of Organizational Health Literacy Practice at Health Care Centers: Outcomes, Barriers and Facilitators. International Journal of Environmental Research and Public Health. 2020; 17(20):7544. https://doi.org/10.3390/ijerph 17207544 PMid:33081335 PMCid:PMC7589923

3. . Carpenter MA, Bauer T, Erdogan B, Short J. Principles of management: Flat World Knowledge Washington, DC; 2009.

4. Seyedin SH, Zaboli R, Malmoon Z, Rajabifard F. General hospital managers' perception regarding crisis management at Iran and Tehran university of medical sciences. Journal of Hospital. 2016;15(2):95-102.

5. Wybo J-L, Fogelman-Soulié F, Gouttas C, Freyssinet É, Lions P. Impact of social media in security and crisis management: a review. International Journal of Emergency Management. 2015;11(2):105-28. https://doi.org/10.1504/IJEM.2015.071045

6. Ghavidel A. Optimal Decision-Making and Management in Media Organizations.The Quarterly Journal of Media Research. 2019;5(1):67-92.

7. Montalvo RE. Social media management. International Journal of Management \& Information Systems (IJMIS). 2011;15(3):91-6. https://doi.org/10.19030/ijmis.v15i3.4645

8. Tehrani H. Media Health Literacy. Journal of Health Literacy. 2016;1(3):141-6. https://doi.org/10.22038/jhl.2016.10853

9. Asgharinekah SM, Sharifi F, Amel Barez M. The Need of Family-Based Sexual Education: A Systematic Review. Journal of Health Literacy. 2019;4(3):25-37.

10. Olyani S, Tehrani H, Esmaily H, Rezaii MM, Vahedianshahroodi M. Assessment of health literacy with the Newest Vital Sign and its correlation with body mass index in female adolescent students. International journal of

$$
\begin{aligned}
& \text { مرتبط با بحران و رسانه در تحقيقات آتى مورد توجه محققان قرار } \\
& \text { كيرد. لازم به ذكر است به موجب محدويتهاى موجود در اين } \\
& \text { تحقيق ساير عوامل موثر بر تصميم گيرى در بحران از جمله عوامل } \\
& \text { اقتصادى, اجتماعى و سياسى برداخته نشده است. } \\
& \text { به دليل نقش رسانهاى اجتماعى در تصميم گيرى در بحران } \\
& \text { برنامه ريزى, طراحى و انجام مطالعات بومى مبتنى بر رويكرد } \\
& \text { ارتقاء روشها و مهارتهاى تصميم گيرى در مواجهه با بحران در }
\end{aligned}
$$

adolescent medicine and health. 2020;32(2):20170103.

11. Habib Zadeh A, Javadian R. Media Strategies in crisis management. Towsee-Quarterly Development of The Human Resource and Logistics. 2011; 5 (18) :103-123.

12. Reuter C, Hughes AL, Kaufhold M-A. Social media in crisis management: $A n$ evaluation and analysis of crisis informatics research. International Journal of Human-Computer Interaction. 2018;34(4):280-94. https://doi.org/10.1080/10447318.2018.1427832

13. Bratu S. The critical role of social media in crisis communication. Linguistic and Philosophical Investigations. 2016(15):232-8.

14. Reuter C, Hughes AL, Kaufhold M-A. Social media in crisis management: An evaluation and analysis of crisis informatics research. International Journal of Human-Computer Interaction. 2018;34(4):280-94. https://doi.org/10.1080/10447318.2018.1427832

15. Anderson J, Soden R, Keegan B, Palen L, Anderson KM. The crowd is the territory: Assessing quality in peer-produced spatial data during disasters. International Journal of Human-Computer Interaction. 2018;34(4):295-310. https://doi.org/10.1080/10447318.2018.1427828

16. PlotnickL, HiltzSR. Software innovationstosupporttheuse of social media by emergency managers. International Journal of Human-Computer Interaction. 2018;34(4):367-81. https://doi.org/10.1080/10447318.2018.1427825

17. Chaturvedi A, Simha A, Wang Z. ICT infrastructure and social media tools usage in disaster/crisis management. 2015

18. Laudy C, Ruini F, Zanasi A, Przybyszewski M, Stachowicz A, editors. Using social media in crisis management: SOTERIA fusion center for managing information gaps. 2017 20th International Conference on Information Fusion (Fusion); 2017: IEEE. https://doi.org/10.23919/ICIF.2017.8009880

19. Flew T, Bruns A, Burgess J, Crawford K, Shaw F, editors. Social media and its impact on crisis communication: 
Case studies of Twitter use in emergency management in Australia and New Zealand. 2013 ICA Shanghai Regional Conference: Communication and Social Transformation; 2014.

20. Pintér DG. Media bias and the role of user generated contents in crisis management: a case-study about the communication of the hungarian police forces after 2016 budapest explosion. Corvinus Journal of Sociology and Social Policy. 2018;9(1):101-1025. https://doi.org/10.14267/CJSSP.2018.1.05

21. Severin WJ, Tankard JW. Communication theories: Origins, methods, and uses in the mass media: Longman New York; 1997.

22. Du Plessis C. Social media crisis communication: Enhancing a discourse of renewal through dialogic content. Public relations review. 2018;44(5):829-38. https://doi.org/10.1016/j.pubrev.2018.10.003

23. Ahmadzadeh Araji S, Danaei A, Abtahi A. Modeling Human Resource Agility and Ethics Management in Resolving the Crisis of Media Organizations. Iranian journal of educational sociology. 2017;1(6):62-70.

24. Liu X, Hu P, editors. Current Situation and Countermeasures of New Media in Crisis Management in Universities. 2018 International Symposium on Social Science and Management Innovation (SSMI 2018); 2019: Atlantis Press. https://doi.org/10.2991/ssmi-18.2019.39

25. Murschetz PC, Friedrichsen M. Making media management research matter. Digital Transformation in Journalism and News Media: Springer; 2017. p. 17-28. https://doi.org/10.1007/978-3-319-27786-8_3

26. Ghassabi F, Zare-Farashbandi F. The role of media in crisis management: A case study of Azarbayejan earthquake. International Journal of Health System and Disaster Management. 2015; 3(2):95. https://doi.org/10.4103/2347-9019.144371

27. Nejad Bakhsh Esfahani A, Bagheri A. The Role of Mass Media in Preventing Crisis. Journal of Communication Research (Pazhoohesh Va Sanjesh). 2009; 15 (56): 137158.

28. Olsson E-K. Media crisis management in traditional and digital newsrooms. Convergence. 2009; 15(4):446-61. https://doi.org/10.1177/1354856509342780

29. Abdel Fattah M, Interweavement-Building a Crisis Decision Making Model for media Rational Responsibility in the media: International Communication, Political crisis management, and the use of Mathematics-A thesis. Heritage Branch.2004. 